\title{
A REVISION OF THE BRÜELIA (MALLOPHAGA) SPECIES INFESTING THE CORVIDAE PART II
}

BY

M. ATIQUR RAHMAN ANSARI

$P p$. I43-I82; I22 Text-figures

BULLETIN OF

THE BRITISH MUSEUM (NATURAL HISTORY) ENTOMOLOGY Vol. 5 No. 4

LONDON : 1957 
THE BULLETIN OF THE BRITISH MUSEUM (NATURAL HISTORY), instituted in I949, is issued in five series corresponding to the Departments of the Museum, and an Historical Series.

Parts will appear at irregular intervals as they become ready. Volumes will contain about three or four hundred pages, and will not necessarily be completed within one calendar year.

This paper is Vol. 5, No. 4 of the Entomological series.

PRINTED BY ORDER OF THE TRUSTEES OF THE BRITISH MUSEUM 


\title{
A REVISION OF THE BRÜELIA (MALLOPHAGA) SPECIES INFESTING THE CORVIDAE
}

\author{
PART II* \\ By M. ATIQUR RAHMAN ANSARI, M.Sc., Ph.D., D.Sc.
}

THE various species of Brïelia Kéler, I936 from the crows, belonging to the genus Corvus, closely resemble each other in their external morphology and have usually been wrongly identified. Among these species there are three distinct groups separated by the characters of the male genitalia; a combination of characters including the shape of the head and abdominal chaetotaxy enables these groups to be further subdivided into convenient subgroups.

In the female, the shape of the head, tergal and genital plates are also found useful in separating species.

Three species viz., Brüelia bipunctata (Rudow), B. latifasciata (Piaget) and $B$. rotundata (Osborn) are included in the present communication as valid names not because we believe them to be so, but because in the absence of the sex, other than from which these are described, we are uncertain of their true status. During these studies we have generally observed that the allied forms are commonly indistinguishable from each other in the females though easily separated in the males. We hesitate therefore to establish a name based on females alone. In order to elucidate this problem, as to whether these names refer to any other known species or not, we think that it is necessary to have collections from the type host and type locality. Before this purpose is achieved, these names are better considered as tentative.

\section{Brïelia argula (Burmeister), 1838}

$$
\text { (Text-figs. I-8, 60-64) }
$$

Nirmus argula Burmeister, 1838, Handb. Ent. $2: 430$.

\section{Type host: Corvus c. corax Linn.}

MALE. Head broader than long and roughly hexagonal in shape. Pre-antennal region triangular, parabolic with slightly flattened anterior margin. Marginal carina entire dorsally and feebly sclerotized medianly. Ventral carina uniformly sclerotized throughout and continuous with the marginal carina. Preocular nodus well developed, continuous with the pre-antennal nodus. Postocular nodus well pigmented. The number and arrangement of setae of head as described by Clay

* Part I appeared in Bull. Brit. Mus. (Nat. Hist.) Ent. 4 (8) : 371-406, 1956.

ENTOM. 5, 4 . 
(I95I). Antennae exhibiting sexual dimorphism, basal segment robust, about I. 5 times as long as in the female.

Prothorax transverse, with a long dorsal hair in the posterior angle. Pterothorax trapezoidal, laterally divergent. Angulate posteriorly, with 8-9 elongate hairs on the dorsal posterior margin on each side.

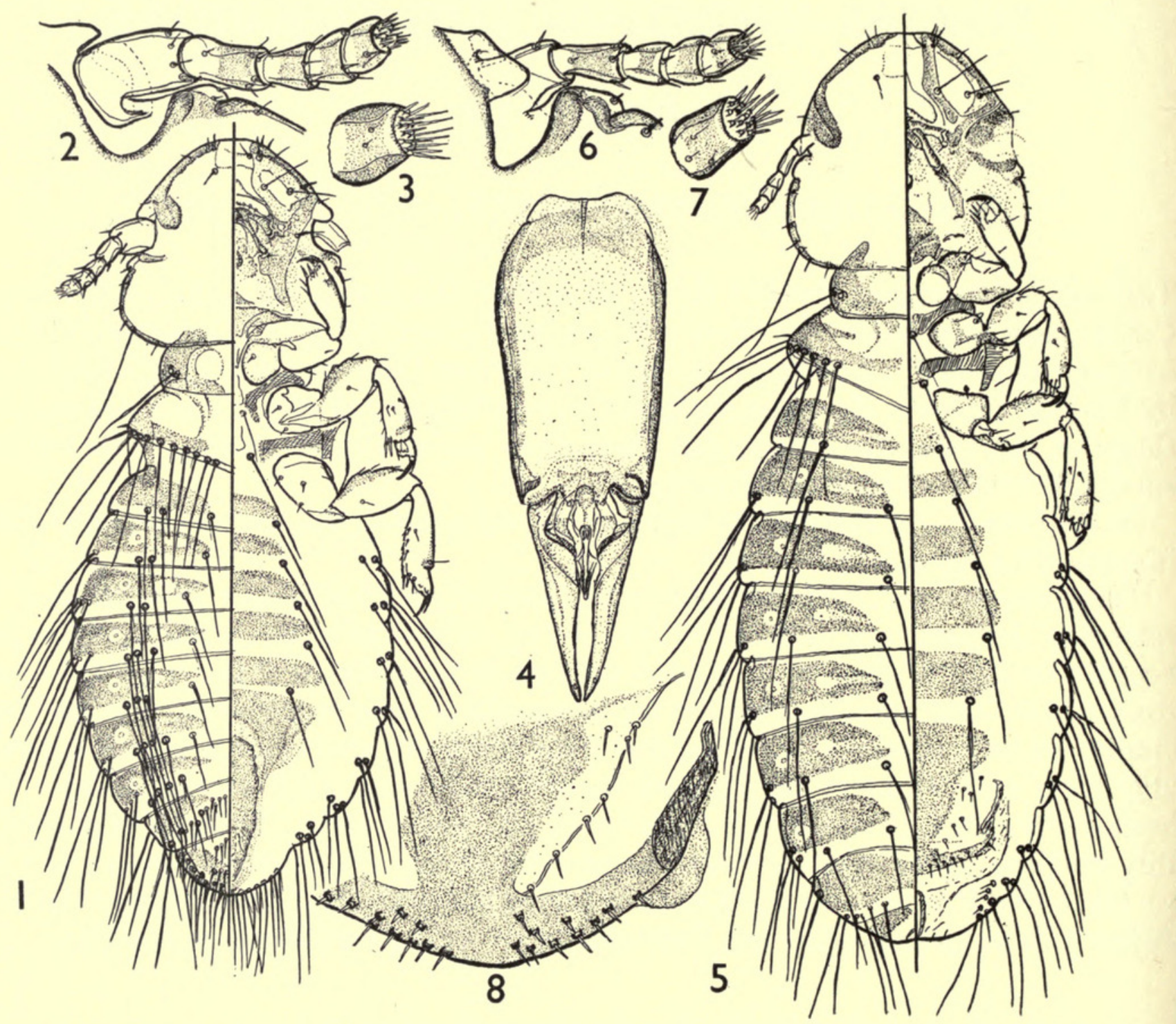

FIGS. I-8.-Brüelia argula (Burmeister). (I) Dorsal and ventral aspects of adult male ;

(2) antenna of male; (3) tip of the same ; (4) male genital armature; (5) dorsal and ventral aspects of adult female; (6) antenna of female ; (7) tip of the same ;

(8) vulvar chaetotaxy.

Abdomen elliptical with broadly rounded terminal segment. Tergal plates well developed, II-VI roughly rectangular, narrow ; VII-VIII tending to be triangular; IX triangular. Sternal plates II-VI well formed, rectangular, narrowed in the middle. Genital plate triangular. Chaetotaxy as shown in the table below, fairly regular in all specimens save some of the small hairs which vary slightly in some specimens.

Genitalia. Basal plate is about $\mathrm{I} \cdot 3-\mathrm{I} \cdot 4$ times as long as the parameres. Mesosomal plate wide anteriorly, concave laterally in the middle and elongated posteriorly. 
The details of the proximal head of parameres, shape of endomeres and telomeres and details of mesosome are of specific value and are shown in the figure.

Female. Similar to male but larger and with scarce tergal chaetotaxy. Tergal plates II-VIII approximate, roughly rectangular; IX entire. Genital blotch triangular with posterior angle prolonged backwards to meet a narrow cross-piece forming an anchor-shaped plate. Vulva with 9-Io spines.

\section{Abdominal Chaetotaxy}

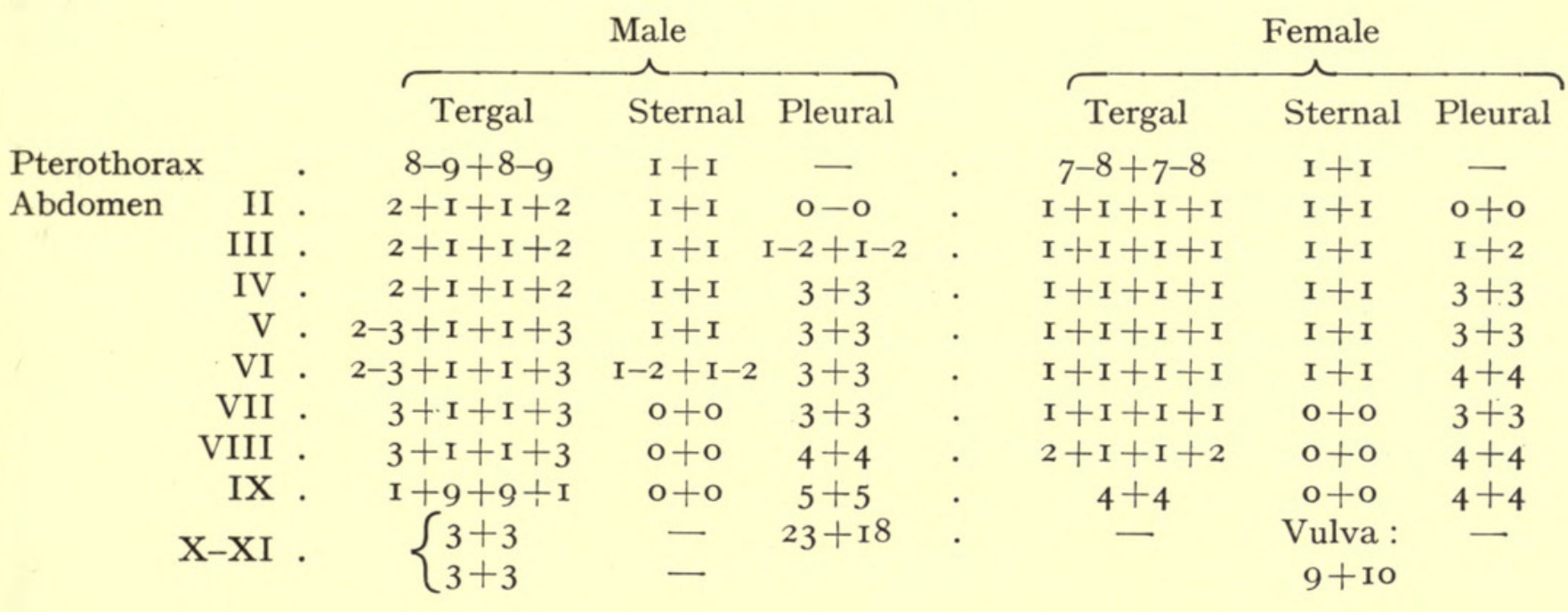

Measurements $(\mathrm{mm}).($ Length $\times$ Breadth $)$

\begin{tabular}{|c|c|c|c|c|c|}
\hline \multirow{3}{*}{\multicolumn{2}{|c|}{$\begin{aligned} \text { Head : pre-antennal } \\
\text { hind head . }\end{aligned}$}} & \multicolumn{3}{|c|}{ Male (neotype) } & Gemale (neallotype \\
\hline & & . & $\mathrm{o} \cdot \mathrm{I} 64 \times 0 \cdot 397$ & . & $0.205 \times 0.45^{2}$ \\
\hline & & . & $0.267 \times 0.479$ & . & $0.288 \times 0.527$ \\
\hline Prothorax & . & . & $\mathrm{O} \cdot \mathrm{IO} 3 \times 0 \cdot 3 \mathrm{I} 5$ & . & $0 \cdot 103 \times 0 \cdot 328$ \\
\hline Pterothorax & . & . & $\mathrm{o} \cdot \mathrm{I} 57 \times 0.465$ & . & $0.205 \times 0.52 \mathrm{I}$ \\
\hline Abdomen & $\cdot \quad \cdot$ & . & $0.924 \times 0.698$ & . & $\mathrm{I} \cdot 2 \mathrm{I} 2 \times 0 \cdot 7 \mathrm{I} 6$ \\
\hline $\mathrm{L}: \mathrm{B}$ of pre- & antennal & . & I $: 2 \cdot 4^{2}$ & . & $\mathrm{I}: 2 \cdot 2 \mathrm{I}$ \\
\hline $\mathrm{L}: \mathrm{B}$ of hind & head & . & I $:$ I $\cdot 79$ & . & $\mathbf{I}: \mathbf{I} \cdot 83$ \\
\hline Cephalic ind & ex & . & I : I $\cdot$ II & . & $\mathbf{I}: \mathbf{I} \cdot 07$ \\
\hline
\end{tabular}

Material examined. Six males and 7 females from Corvus corax corax Linn. from Uist and Russia in British Museum (Nat. Hist.) Collection.

Neotype (male) of Brüelia argula (Burmeister) and neallotype (female) on slide no. I4562 in Meinertzhagen collection (British Museum) (Nat. Hist.) from Corvus corax corax Linn. Neoparatypes: 5 males and 6 females from the same host (data above).

Fifty-four males and 74 females from Corvus corax laurencei Hume from Chorband and Kabul (Afghanistan), Palestine and Lyallpur (Pakistan), 20 males and 6 females from Corvus corax ruficollis and 5 males and 74 females from Corvus corax tingitanus from Egypt, Morocco, North Africa and Teneriffe in Meinertzhagen collection were found to be indistinguishable from Brüelia argula. 


\section{Brïelia leucocephalus (Nitzsch), I866}

(Text-figs. 9, 26-27, 65-68)

Nirmus leucocephalus, Nitzsch, I866, Z. ges. Natwiss. $28: 365$.

Type host : Corvus albicollis Latham.

Brüelia leucocephalus is closely allied to $B$. argula from which it differs in the abdominal chaetotaxy. From the other allied forms viz., B. quadrangularis and $B$. theresae it differs in the shape of the head.

MALE. Head broader than long; pre-antennal region less than half the region behind. Marginal carina entire. Dorsal suture well marked. Antennae well built, basal segment robust. Tergal plates II-IX narrow, approximate, well sclerotized; III-VI ensiform with two clear, or faintly pigmented circular areas. Sternal plates II-VI well formed. Genital plate triangular. Genitalia of the type found in Brüelia argula. Basal plate broader anteriorly and narrow posteriorly. Parameres slightly longer and broader than in $B$. quandrangularis. The characters of the proximal head of parameres, endomeres and mesosome are also different.

Female. Similar to male but the measurements are greater. The abdominal chaetotaxy also differs considerably.

\section{Abdominal Chaetotaxy}

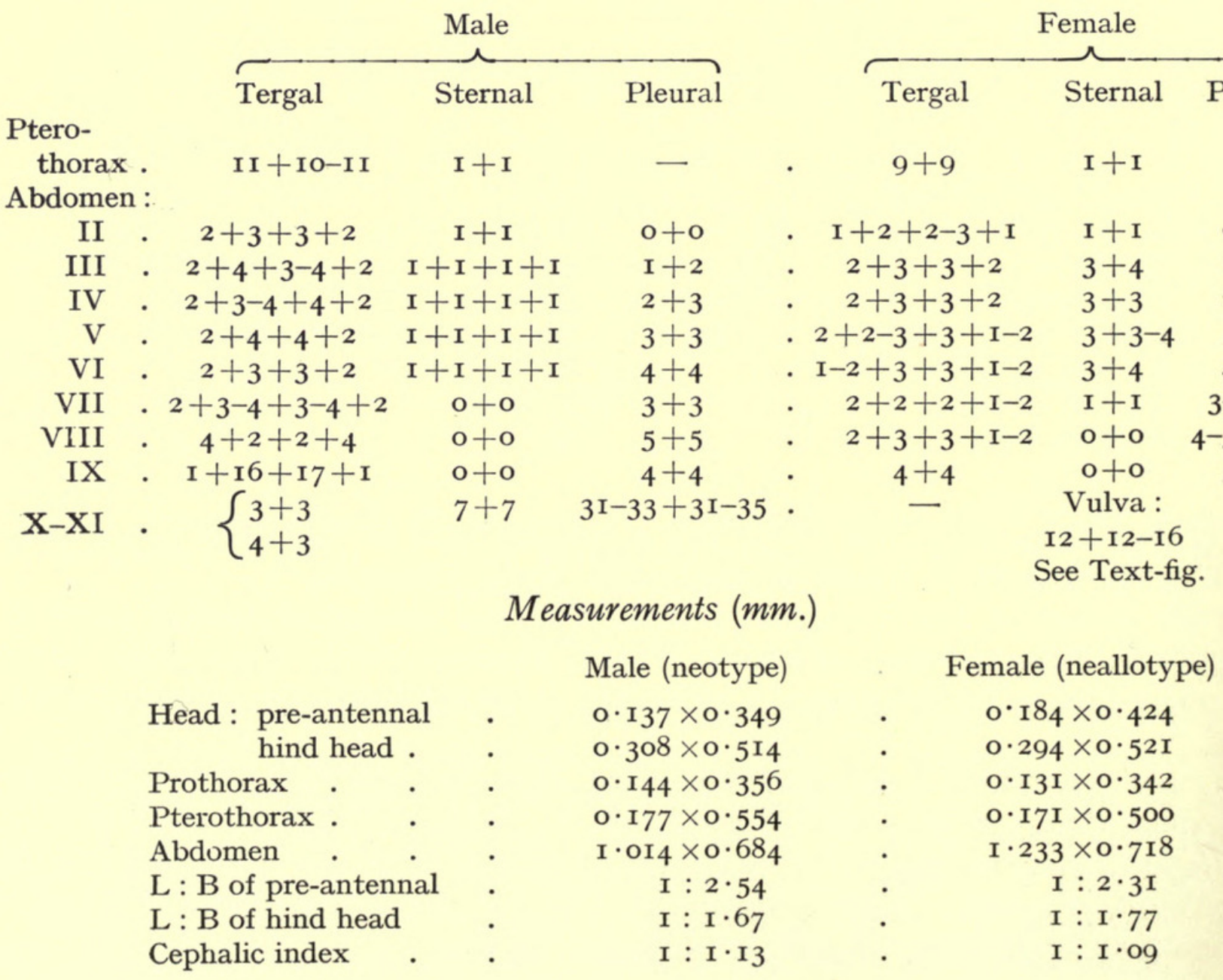



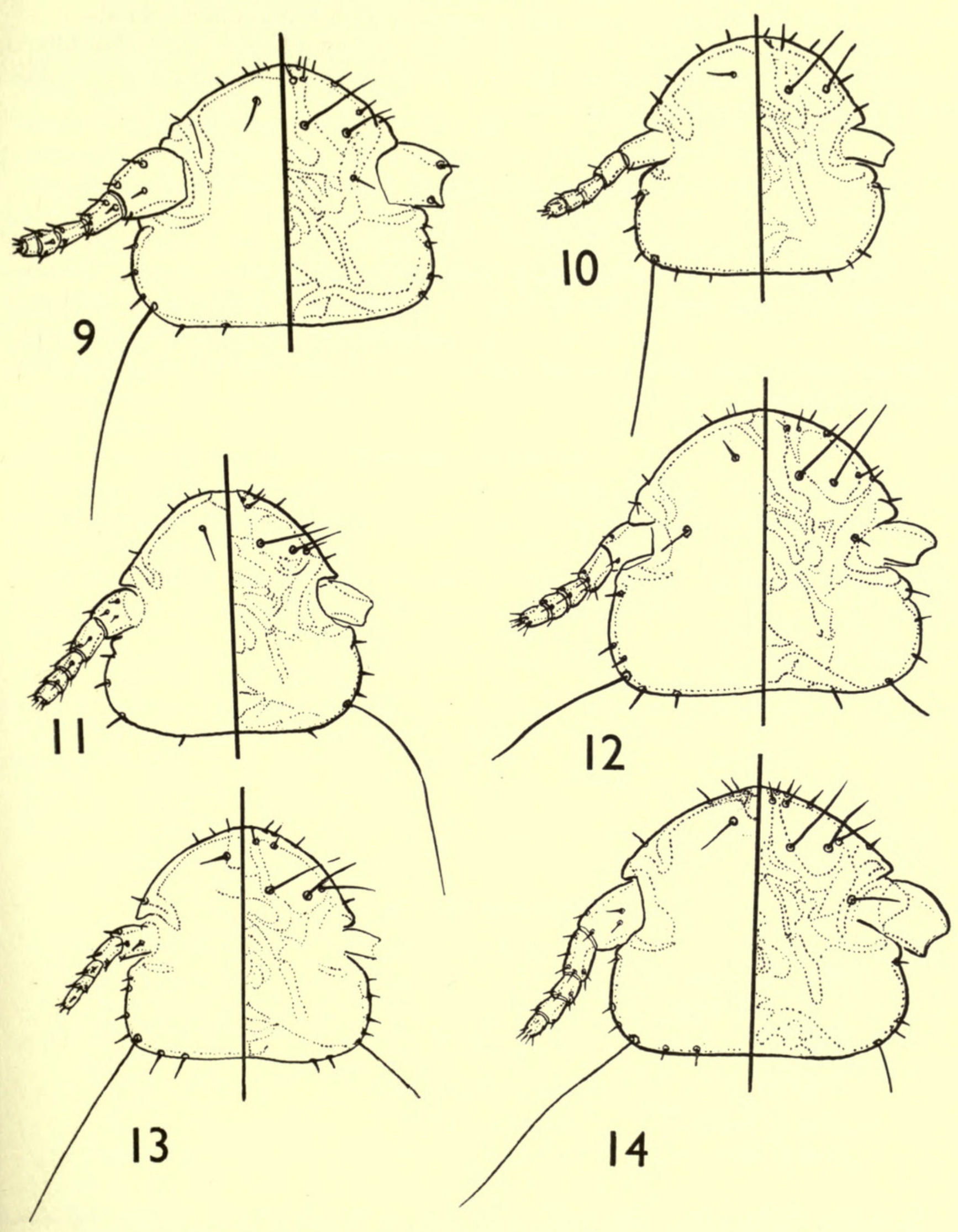

FIgs. 9-I4. Heads of adult males: (9) Brüelia lecocephalus (Nitzsch); (Io) Brüelia theresae, sp. nov. ; (II) Brüelia quadrangularis (Rudow); (I2) Brüelia tasniemae sp. nov. ; (13) Brüelia variegata sp. nov. ; (I4) Brüelia afzali sp. nov. 
Material eXAmined. Twelve males and 20 females from Corvus albicollis Latham, from Basutoland, Tanganyika, Kenya, South Nigeria and Uganda.

Neotype (male) and neallotype (female) from Corvus albicollis from Basutoland, Swedish South African Expedition I950-5I. Neoparatypes : II males and I9 females from the same host species (data above).

\section{Brïelia theresae sp. nov.}

(Text-figs. I0, 28-29, 69-73)

This species resembles Brüelia argula (Burmeister) in all general details, but there is considerable difference in the abdominal chaetotaxy of both sexes. The male genitalia also differ in the details of the proximal head of the parameres. The shape of the endomeres and telomeres and details of mesosome are similar to that found in Brüelia argula.

\section{Abdominal Chaetotaxy}

\begin{tabular}{|c|c|c|c|c|c|c|c|c|}
\hline & & $\mathrm{Ma}$ & (holotyr & & & & nale (allotype & \\
\hline & & Tergal & Sternal & Pleural & & Tergal & Sternal & Pleural \\
\hline $\begin{array}{l}\text { Pterothora } \\
\text { Abdomen : }\end{array}$ & & $9+9$ & $\mathbf{I}+\mathbf{I}$ & 一 & . & $8+7$ & $\mathbf{I}+\mathbf{I}$ & $0+0$ \\
\hline II & . & $2+3+3+2$ & $\mathbf{I}+\mathbf{I}$ & $0+0$ & . & $I+3+3+I$ & $\mathbf{I}+\mathbf{I}$ & $I+2$ \\
\hline III & . & $2+3+3+2$ & $\mathbf{I}+\mathbf{I}$ & $\mathbf{I}+\mathbf{I}$ & . & $I+2+3+I$ & $I+I+I+I$ & $2+2$ \\
\hline IV & . & $2+3+3+2$ & $I+I$ & $2+2$ & . & $I+2+2+I$ & $I+I+I+I$ & $2+2$ \\
\hline $\mathrm{V}$ & . & $2+2+3+2$ & $\mathbf{I}+\mathbf{I}$ & $2+2$ & . & $I+2+2+I$ & $I+I+I+I$ & $2+3$ \\
\hline VI & . & $2+2+2+2$ & $\mathbf{I}+\mathbf{I}$ & $3+3$ & . & $\mathbf{I}+\mathbf{I}+\mathbf{I}+\mathbf{I}$ & $\mathbf{I}+\mathbf{I}+\mathbf{I}+\mathbf{I}$ & $2+3$ \\
\hline VII & . & $2+2+3+2$ & $0+0$ & $2+3$ & . & $\mathbf{I}+\mathbf{I}+\mathbf{I}+\mathbf{I}$ & $0+o$ & $2+3$ \\
\hline VIII & . & $6+5$ & $0+0$ & $3+3$ & . & $\mathbf{I}+\mathbf{I}$ & $o+o$ & $4+4$ \\
\hline IX & . & $\mathrm{I}+8+8+\mathrm{I}$ & $0+0$ & $3+3$ & . & $2+2$ & $0+0$ & - \\
\hline $\mathrm{X}-\mathrm{XI}$ & . & $3+3$ & $3+3$ & $23+22$ & . & - & $\begin{array}{r}\text { Vulva: } \\
9+\text { Io }\end{array}$ & - \\
\hline
\end{tabular}

\section{Measurements $(\mathrm{mm}$.}

\begin{tabular}{|c|c|c|c|c|c|}
\hline \multirow{3}{*}{\multicolumn{2}{|c|}{$\begin{aligned} \text { Head : } & \text { pre-antennal } \\
& \text { hind head } .\end{aligned}$}} & \multicolumn{3}{|c|}{ Male (holotype) } & \multirow{2}{*}{$\begin{array}{c}\text { Female (allotype) } \\
0.184 \times 0.383\end{array}$} \\
\hline & & - & $0 \cdot 157 \times 0.349$ & . & \\
\hline & & $\cdot$ & $0.253 \times 0.417$ & . & $0.253 \times 0.45^{2}$ \\
\hline Prothorax & . & . & $0.103 \times 0.28 \mathrm{I}$ & . & $0.103 \times 0.288$ \\
\hline Pterothorax & . & . & $0.15 I \times 0.43 I$ & . & $0.15 \mathrm{I} \times 0.45^{2}$ \\
\hline Abdomen & . & . & $0.897 \times 0.547$ & . & $\mathrm{I} \cdot 027 \times 0.582$ \\
\hline $\mathrm{L}: \mathrm{B}$ of pre- & antennal & . & $I: 2 \cdot 22$ & . & I $: 2 \cdot 08$ \\
\hline $\mathrm{L}: \mathrm{B}$ of hind & 1 head & 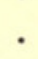 & $I: I \cdot 64$ & . & $\mathrm{I}: \mathrm{I} \cdot 78$ \\
\hline Cephalic ind & ex . & . & $\mathrm{I}: \mathrm{I} \cdot 02$ & . & I : I $\cdot 03$ \\
\hline
\end{tabular}

Material eXamined. Eighteen males and 29 females from Corvus rhipidurus from Aden. Holotype (male) and allotype (female), slide no. I7849 in Meinertzhagen collection (British Museum (Nat. Hist.)) from Corvus rhipidurus Hartest from Aden. Paratypes: I7 males and 28 females from the type host (data above). 


\section{Brïelia quadrangularis (Rudow), $\mathrm{I} 869$}

(Text-figs. II, 30-3I)

Nirmus quadrangularis Rudow, 1869, Beitr. Kenntn. Malloph. : 18.

Type host : Corvus albus Müller.

Brüelia quandrangularis is allied to $B$. argula, from which it differs in chaetotaxy. It differs from $B$. theresae and $B$. leucocephalus in the shape of the head.

Rudow described two species of Nirmus from Corvus scapulatus (= Corvus albus Müller). Hopkins \& Clay (unpublished records) have pointed out that the earlier description (I869, p. I8, B. quadrangularis) fits the broad-headedform while the other (I870, p. 467, bipunctata) fits the narrow-headed form. In the British Museum collection both of these forms from the type host are represented, but the broadheaded forms were found to predominate.

MALE. Head broad, pre-antennal region almost as long as the postantennal region. Marginal carina entire, medianly less sclerotized and concave. Dorsal suture present. Ventral carina fused with the ventrally interrupted marginal carina. Temporal carinae well formed.

Abdomen with narrow tergal plates on segments II-IX. Sternal plates II-VI well formed, rectangular. Genital plate triangular, occupying segments VI-IX.

Genitalia as in B. argula.

Female. Similar to the male in general body markings. Tergal plate IX entire. There is, however, considerable difference in abdominal chaetotaxy.

Abdominal Chaetotaxy

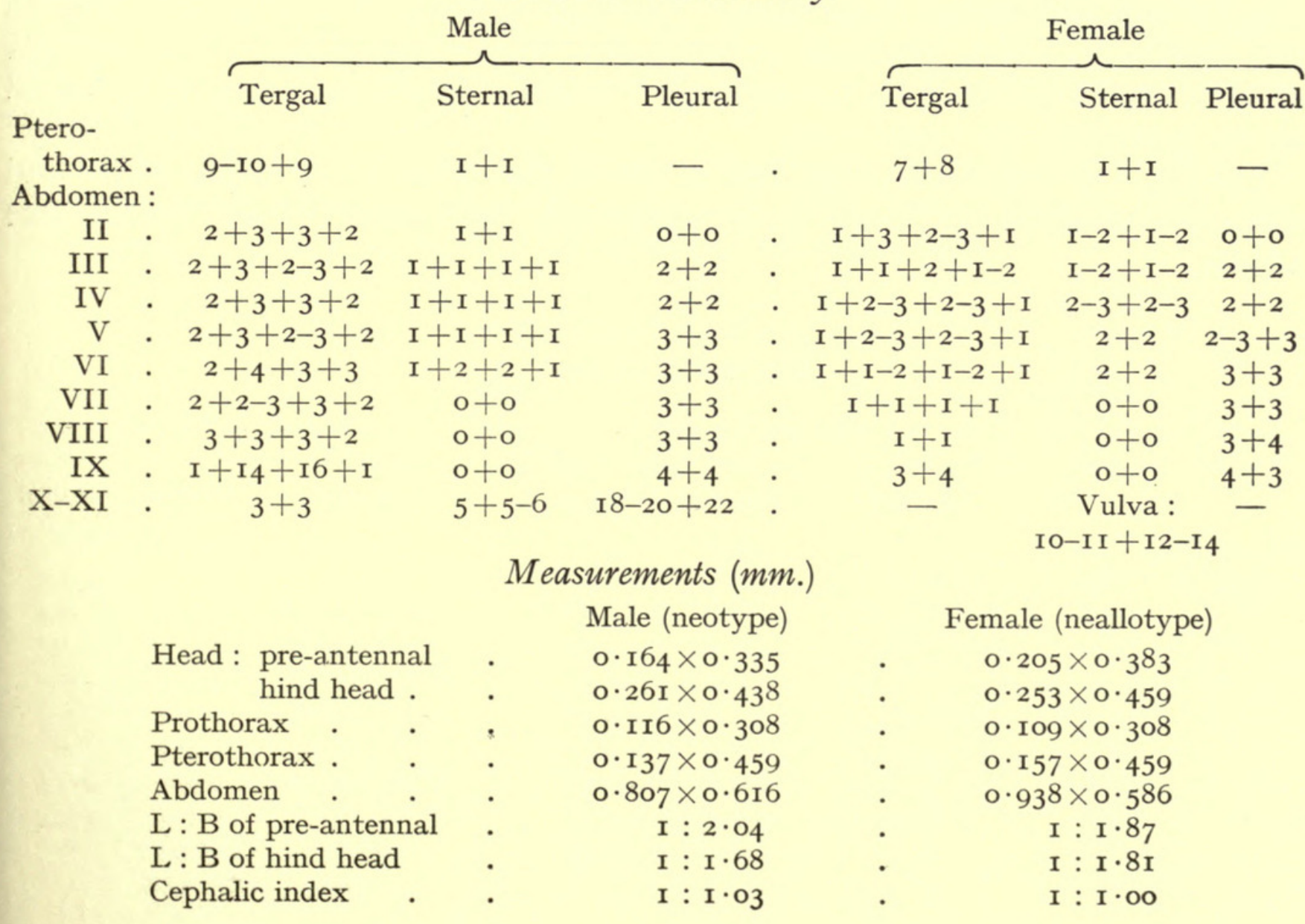


Material examined. Ten males and 22 females from the type host, Corvus albus Müller from Kenya, Tanganyika, Sudan, South West Africa.

Neotype (male) and neallotype (female) from Corvus albus Müller from South West Africa on slide no. I9I80-9I in Meinertzhagen collection (British Museum (Nat. Hist.)). Neoparatypes: 9 males and 2I females from the type host (data above.)

Fourteen males and I7 females from Corvus corax edithae from Somaliland (two localities) are indistinguishable from the above specimens.

\section{Brïelia tasniemae sp. nov.}

(Text-figs. I2, 32-33, 74-78)

This species resembles Brïelia uncinosa (Burmeister) in the shape of the head, from which it can be easily distinguished by the tergal plates. From the other allied forms it differs in the shape of the head, in the development of the marginal carina and ventral carina.

MALE. Fore head rounded. Marginal carina narrow, entire, although less heavily sclerotized in front and indented so as to leave a hyaline margin at this point. Preocular nodus well pigmented. Postocular nodus well developed but not well pigmented. Ventral carina well formed, pigmented in the anterior portion alone. Tergal plates triangular, III-VII with medianly depressed anterior and posterior margins and two circular clear spaces. Genitalia as shown in the figure, similar to that found in B. argula, but differ in the shape of the mesosomal plate. The genitalia are also like those found in $B$. uncinosa. The latter species can be easily separated by the pattern of the tergal plates.

Female. Similar to the male, but differs in size of the body, tergal plates and abdominal chaetotaxy. Tergal plates rectangular, with anterior ends opening like a beak.

\section{Abdominal Chaetotaxy}

\begin{tabular}{|c|c|c|c|c|c|c|c|c|}
\hline & & Mal & (holotype & & & Femal & (allotype & \\
\hline & & Tergal & Sternal & Pleural & & Tergal & Sternal & Pleural \\
\hline Pterothorax & . & $9+7$ & $I+I$ & 一 & . & $9+7$ & $I+I$ & $\rightarrow$ \\
\hline Abdomen II & - & $I+I$ & $I+I$ & $0+0$ & . & $I+I$ & $I+I$ & $0+0$ \\
\hline III & . & $I+I+I+I$ & $I+I$ & $I+I$ & . & $I+I+I+I$ & $I+I$ & $I+I$ \\
\hline IV & . & $2+I+I+2$ & $2+3$ & $3+2$ & . & $I+I+I+I$ & $I+I$ & $2+2$ \\
\hline V & - & $2+2+2+2$ & $2+2$ & $2+2$ & . & $\mathbf{I}+\mathbf{I}+\mathbf{I}+\mathbf{I}$ & $2+2$ & $2+2$ \\
\hline VI & . & $2+3+3+2$ & $2+2$ & $2+3$ & . & $\mathbf{I}+\mathbf{I}+\mathbf{I}+\mathbf{I}$ & $2+2$ & $3+3$ \\
\hline VII & . & $2+3+3+2$ & $0+o$ & $2+2$ & . & $I+I+I+I$ & $o+o$ & $3+3$ \\
\hline VIII & . & $3+2+2+3$ & $0+0$ & $4+4$ & - & $I+I+I+I$ & $o+o$ & $4+4$ \\
\hline IX & & $I+8+9+I$ & $0+0$ & $4+4$ & • & $3+3$ & $0+0$ & $4+4$ \\
\hline $\mathrm{X}-\mathrm{XI}$ & . & $3+3$ & - & $\mathrm{I}_{5}+\mathrm{I}_{5}$ & . & 一 & $\begin{array}{l}\text { Vulvae: } \\
\mathrm{I}_{3}+\mathrm{I} 2\end{array}$ & - \\
\hline
\end{tabular}




\section{Measurements (mm.)}

\begin{tabular}{|c|c|c|c|c|c|}
\hline \multirow{3}{*}{\multicolumn{2}{|c|}{$\begin{aligned} \text { Head : } & \text { pre-antennal } \\
& \text { hind head . }\end{aligned}$}} & \multicolumn{3}{|c|}{ Male (holotype) } & \multirow{2}{*}{$\begin{array}{c}\text { Female (allotype) } \\
0.219 \times 0.486\end{array}$} \\
\hline & & ${ }^{\circ}$ & $0.184 \times 0.424$ & . & \\
\hline & & . & $0.28 \mathrm{I} \times 0.52 \mathrm{I}$ & . & $0.294 \times 0.56 \mathrm{I}$ \\
\hline Prothorax & . & . & $0.096 \times 0.328$ & . & $0 \cdot 109 \times 0 \cdot 349$ \\
\hline Pterothorax & . & . & $0.226 \times 0.534$ & . & $0.226 \times 0.534$ \\
\hline Abdomen & . & . & $I \cdot 000 \times 0 \cdot 712$ & . & $\mathrm{I} \cdot 356 \times 0.800$ \\
\hline $\mathrm{L}: \mathrm{B}$ of pre- & antennal & . & $\mathrm{I}: 2 \cdot 3 \mathrm{I}$ & . & $\mathrm{I}: 2 \cdot 2 \mathrm{I}$ \\
\hline $\mathrm{L}: \mathrm{B}$ of hinc & head & . & I $: I \cdot 85$ & . & $I: I \cdot 9 I$ \\
\hline Cephalic ind & ex . & . & $\mathrm{I}: \mathrm{I} \cdot \mathrm{I} 2$ & . & I : I $\cdot 09$ \\
\hline
\end{tabular}

MATERIAL EXAMINED. Four males and Io females from Corvus frugilegus frugilegus Linn. from Kabul. Holotype (male), allotype (female) from Corvus frugilegus frugilegus Linn. from Kabul on slide no. 9686 in Meinertzhagen collection. Paratypes : 3 males and 9 females from the same host (data above).

\section{Brïelia variegata sp. nov.}

(Text-figs. I3, 34-35, 79-82)

This species is similar to the above species from which it can be distinguished by the genitalia, and the size and shape of the head, which is rounded in front.

MALE. Marginal carina very narrow, entire, feebly sclerotized and slightly depressed in the middle. Ventral carina not well developed, approximate. Basal antennal segment not so robust as in the allied species. Tertal plates II-VI almost rectangular, with interrupted colourless areas in the middle, VII-IX triangular. Male genitalia as shown in the figures. Parameres comparatively short and robust, with well developed proximal heads.

Female. Similar to the male, but the measurements and chaetotaxy differ and cannot be easily separated from the females of allied forms. Genital plate with almost straight sides so as to form a very obtuse terminal angle.

\section{Abdominal Chaetotaxy}

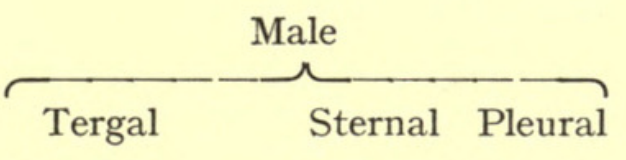

Pterothorax .

Abdomen :

$\begin{array}{rcc}\text { II } & \cdot & 2+\mathrm{I}+\mathrm{I}+2 \\ \text { III } & \cdot & 2+\mathrm{I}+\mathrm{I}+2 \\ \mathrm{IV} & \cdot & 2+\mathrm{I}+\mathrm{I}+2 \\ \mathrm{~V} & \cdot & 2+\mathrm{I}-2+\mathrm{I}-2+2 \\ \mathrm{VI} & \cdot & 2+\mathrm{I}-2+3+2 \\ \mathrm{VII} & \cdot & 2+2+2+2 \\ \mathrm{VIII} & \cdot & \mathrm{I}+4+2-5+\mathrm{I} \\ \mathrm{IX} & \mathrm{I}+6-7+6-7+\mathrm{I} \\ \mathrm{X}-\mathrm{XI} & . & 3+3\end{array}$

$\mathbf{I}+\mathbf{I}$

$\mathbf{I}+\mathbf{I}$

$I+I$

$\mathrm{I}+\mathrm{I}$

$\mathbf{I}+\mathbf{I}$

$I+I$

$\mathrm{o}+\mathrm{o}$

$\mathrm{o}+\mathrm{o}$

$\mathrm{o}+\mathrm{o}$

$\mathrm{o}+\mathrm{O} \quad \mathrm{I}_{4}+\mathrm{I} 5$

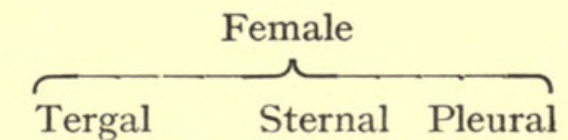

$6-7+6-7$

$$
\text { I }+ \text { I }
$$

$\mathbf{I}+\mathbf{I}+\mathbf{I}+\mathbf{I}$

$\mathbf{I}+\mathbf{I}+\mathbf{I}+\mathbf{I}$ I + I

$\mathrm{I}+2+\mathrm{I}+\mathrm{I}$

$\mathrm{I}+2+\mathrm{I}+\mathrm{I}$

$\mathrm{I}+\mathrm{I}+\mathrm{I}+\mathrm{I}$

$\mathrm{I}+\mathrm{I}+\mathrm{I}+\mathrm{I}$

$3+3$

$$
\begin{array}{cc}
\mathrm{I}+\mathrm{I} & \mathrm{O}+\mathrm{O} \\
\mathrm{I}+\mathrm{I} & \mathrm{I}+\mathrm{I} \\
\mathrm{I}+\mathrm{I} & 2-3+2-3 \\
\mathrm{I}+\mathrm{I} & 2-3+2-3 \\
\mathrm{I}-2+\mathrm{I}-2 & 3+3 \\
\mathrm{O}+\mathrm{o} & 3+3 \\
\mathrm{o}+\mathrm{o} & 3+3 \\
\text { o+o } & 2+2 \\
\text { Vulva: } & - \\
\text { 8-Io+8 } &
\end{array}
$$




\section{Measurements (mm.)}

\begin{tabular}{|c|c|c|c|c|c|}
\hline \multirow{3}{*}{\multicolumn{2}{|c|}{$\begin{aligned} \text { Head : pre-antennal } \\
\text { hind head . }\end{aligned}$}} & \multicolumn{3}{|c|}{ Male (holotype) } & \multirow{2}{*}{$\begin{array}{c}\text { Female (allotype) } \\
0.177 \times 0.377\end{array}$} \\
\hline & & $\cdot$ & $0.157 \times 0.369$ & . & \\
\hline & & . & $0.239 \times 0.424$ & . & $0.234 \times 0.45^{2}$ \\
\hline Prothorax & . $\quad$. & • & $0 \cdot 103 \times 0.246$ & . & $0.109 \times 0.253$ \\
\hline Pterothorax & . & . & $0.137 \times 0.397$ & . & $0.137 \times 0.391$ \\
\hline Abdomen & . & . & $0.876 \times 0.547$ & . & $\mathrm{I} \cdot \mathrm{I} 3 \mathrm{I} \times 0.568$ \\
\hline \multicolumn{2}{|c|}{$\mathrm{L}: \mathrm{B}$ of pre-antennal } & . & I $: 2 \cdot 35$ & . & I $: 2 \cdot 13$ \\
\hline \multicolumn{2}{|c|}{$\mathrm{L}: \mathrm{B}$ of hind head } & . & I $: \mathbf{I} \cdot 77$ & . & I : I $\cdot 93$ \\
\hline \multicolumn{2}{|c|}{ Cephalic index . } & . & I : I IO & . & I : I $\cdot$ IO \\
\hline
\end{tabular}

MATERial EXAmined. Four males and $\mathrm{I}_{5}$ females from Corvus capensis from Somaliland, Transvaal, and Damaraland. Holotype (male) and allotype (female) on slide no. 18329 from Corvus capensis Licht. from Somaliland, in the Meinertzhagen collection (British Museum (Nat. Hist.)). Paratypes: 3 males and I4 females from the same host (data above).

\section{Brïelia afzali sp. nov.}

(Text-figs. I4, 36-37, 83-87)

This species resembles Brüelia leucocephalus in the shape of the head, and $B$. uncinosa in the form of the male genitalia. From the latter it differs in the shape of tergal plates. It also resembles $B$. tasniemae sp. nov. and $B$. variegata sp. nov. from both of which it is distinguished by the squat and broad fore head and well developed first antennal segment in the male.

MALE. Fore head very squat and broader than long. Marginal carina narrow. Ventral carina well developed. Preocular nodus well pigmented and fused with pre-antennal nodus. Postocular nodus not well pigmented. Antennae well developed, antennal segment I very robust. Tergal plates well developed, II-VI wedge-shaped, VII-IX triangular. Male genitalia of the pattern seen in the species referred to above.

Female. Similar to male. Ventral setae of pleural plate IX elongate.

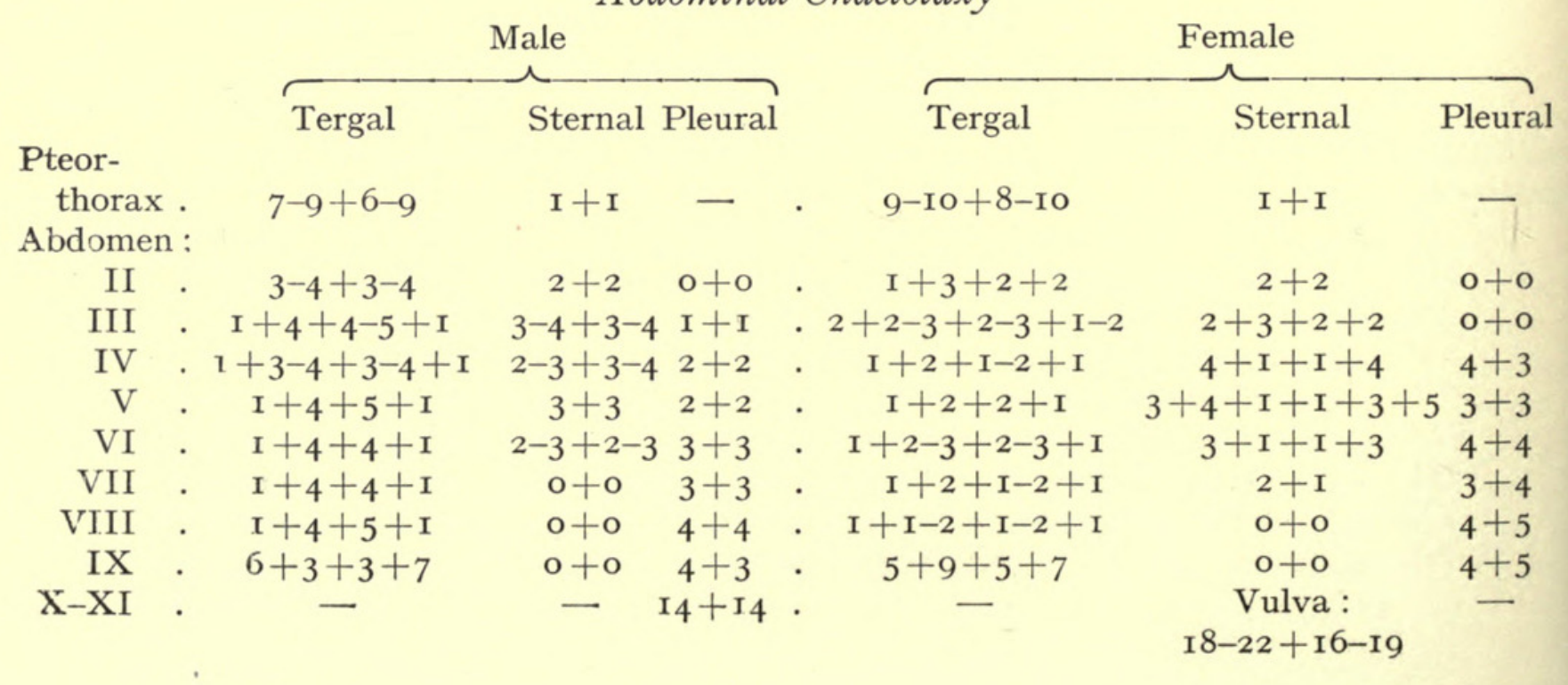

Abdominal Chaetotaxy 


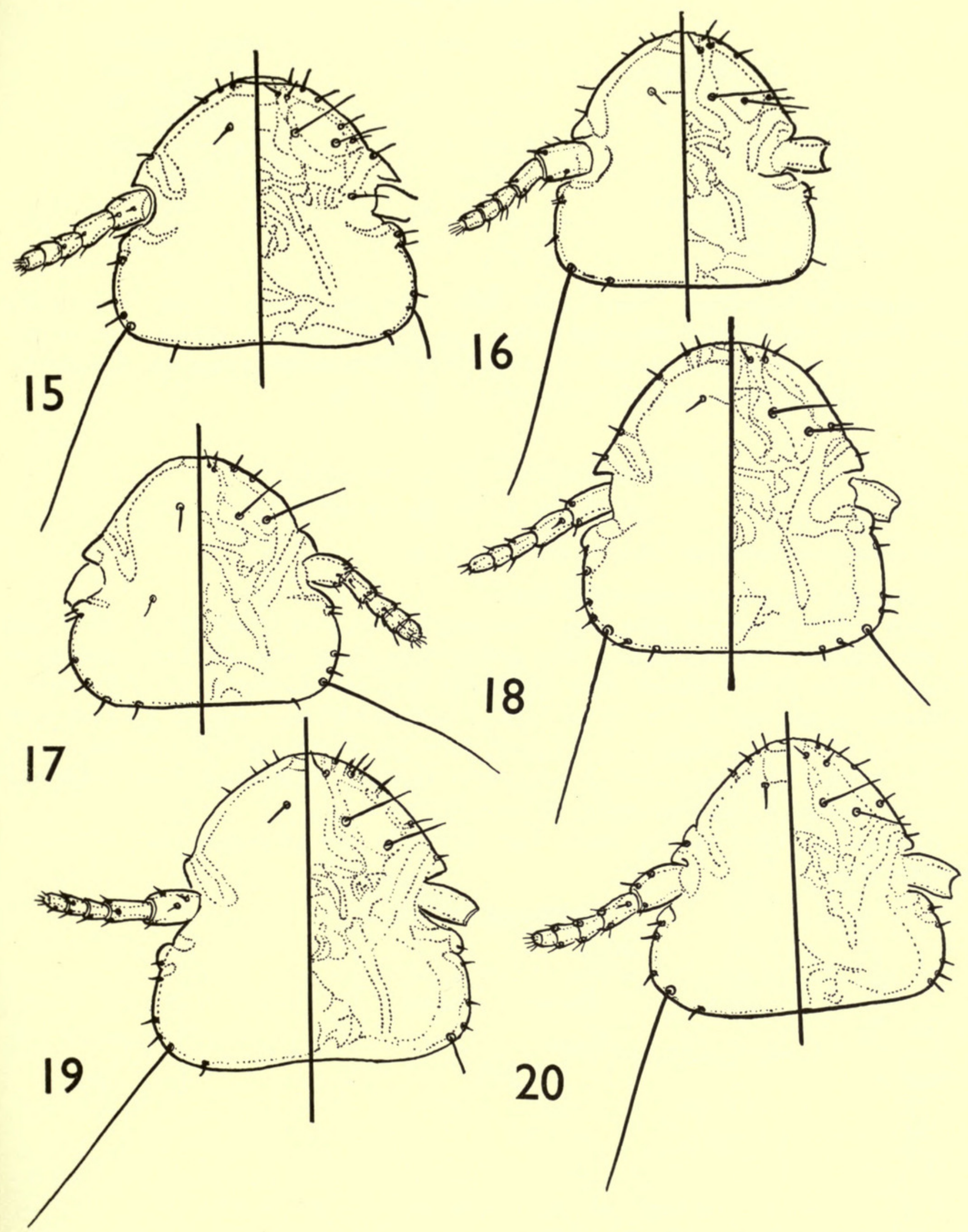

FIGs. I5-20. Heads of adult males : (I5) Brüelia uncinosa (Burmeister); (I6) Brüelia saliemi sp. nov.; (I7) Brüelia saliemi mollii ssp. nov.; (I8) Brüelia atherae sp. nov.; (I9) Brüelia cryptoleucus sp. nov. ; (20) Brüelia varia (Burmeister).

ENTOM. 5, 4. 


\section{Measurements (mm.)}

Head : pre-antennal
hind head .
Prothorax.
Pterothorax.
Abdomen.
L : B of pre-antennal
L : B of hind head
Cephalic index

$$
\begin{gathered}
\text { Female (allotype) } \\
0 \cdot 2 \mathrm{I} 9 \times 0.507 \\
0 \cdot 308 \times 0.554 \\
0 \cdot 1 \mathrm{I} 6 \times 0.335 \\
0 \cdot 239 \times 0.486 \\
\mathrm{I} \cdot 28 \mathrm{I} \times 0.774 \\
\mathrm{I}: 2 \cdot 3 \mathrm{I} \\
\mathrm{I}: \mathrm{I} \cdot 79 \\
\mathrm{I}: \mathrm{I} \cdot 05
\end{gathered}
$$

MATERIAL EXAMined. Four males and 6 females from Corvus cryptoleucus from Texas and Illinois. Holotype (male) and allotype (female) from Corvus cryptoleucus Couch from Illinois on slide no. I2668 in Meinertzhagen collection. Paratypes: 3 males and 5 females from the same host (data above).

\section{Brüelia uncinosa (Burmeister), I838}

(Text-figs. I5, 38-39, 88-9I)

Nirmus uncinosa Burmeister, 1838, Handb. Ent. 2 : 430.

Type host : Corvus corone cornix Linn.

MALE. Head broader than long. Marginal carina entire, but faintly sclerotized in the middle. Ventral carina very feebly sclerotized and not well pigmented. Tergal plates II-III lateral, well pigmented near the stigmata, IV-VIII with a posterior pigmented arm so as to form a horizontally-laid sign of interrogation. Sternal plates II-VI transverse. Genital plate well developed. Genitalia as shown in the figure. Proximal head of parameres narrow. Mesosomal plate polygonal, shape of endomeres and telomeres characteristic.

Female. Similar to the male, but differs in measurements and abdominal chaetotaxy.

\section{Abdominal Chaetotaxy}

$\overbrace{\text { Tergal }}^{\text {Male }} \underbrace{\text { Pleural }}_{\text {Sternal }}$

Ptero-

thorax .

$$
\text { 9-10+9-10 }
$$

$\mathbf{I}+\mathbf{I}$

Abdomen :

$$
\begin{array}{rcc}
\mathrm{II} & . & \mathrm{I}+\mathrm{I}+\mathrm{I}+\mathrm{I} \\
\mathrm{III} & . & \mathrm{I}+\mathrm{I}+\mathrm{I}+\mathrm{I} \\
\mathrm{IV} & \cdot & 2+\mathrm{I}-2+\mathrm{I}-2+2 \\
\mathrm{~V} & \cdot & 3+\mathrm{I}-2+\mathrm{I}-2+2-3 \\
\mathrm{VI} & \cdot & 2-3+2-3+3+2-3 \\
\mathrm{VII} & \cdot & 2-3+2-3+2-3+2-3 \\
\mathrm{VIII} & \cdot & 2-3+2+2+3 \\
\mathrm{IX} & \cdot & \mathrm{I}+9-\mathrm{I} 2+\mathrm{IO}-\mathrm{I} 3+\mathrm{I} \\
\mathrm{X}-\mathrm{XI} & \cdot & \left\{\begin{array}{l}
3+3 \\
3+3
\end{array}\right.
\end{array}
$$$$
2+2
$$

$2+2$

$$
\begin{array}{r}
2+2 \\
2-3+2
\end{array}
$$$$
2-3+3
$$$$
\mathrm{o}+\mathrm{O}
$$$$
\mathrm{o}+\mathrm{o}
$$$$
\mathrm{o}+\mathrm{o}
$$

-
$0+0$
$\mathrm{I}+\mathrm{I}$
$2+2$
$2-3+2$
$2-3+3$
$3+3$
$3-4+4$
$4-5+4-5$

$\overbrace{\text { Tergal }}^{\text {Female }}$



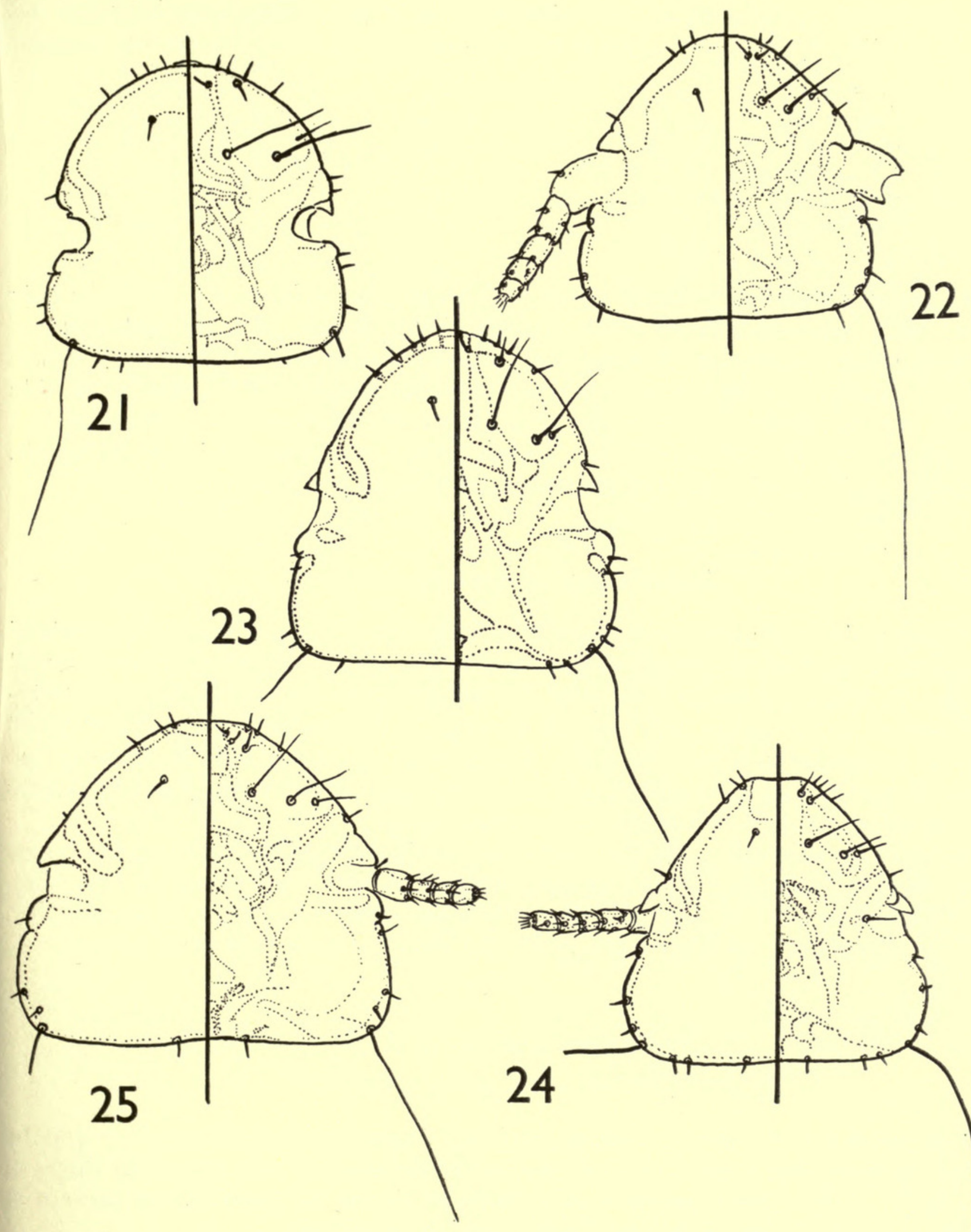

Figs. 2I-25. Heads of adult males: (2I) Brüelia nawabi sp. nov; (22) Brüelia perwienae sp. nov. (23-25) Heads of adult females: (23) Brüelia bipunctata (Rudow); (24) Brüelia latifasciata (Piaget); (25) Brüelia rotundata (Osborn). 
Measurements (mm.)

\begin{tabular}{|c|c|c|c|c|c|}
\hline \multirow{3}{*}{\multicolumn{2}{|c|}{$\begin{aligned} \text { Head : } & \text { pre-antennal } \\
& \text { hind head . }\end{aligned}$}} & \multicolumn{3}{|c|}{ Male (neotype) } & Female (neallotype \\
\hline & & . & $0.199 \times 0.472$ & . & $0.199 \times 0.509$ \\
\hline & & . & $0.318 \times 0.582$ & . & $0.318 \times 0.609$ \\
\hline Prothorax & . & . & $0.127 \times 0.345$ & . & $0.127 \times 0.345$ \\
\hline Pterothorax & . & . & $0.318 \times 0.545$ & . & $0.336 \times 0.545$ \\
\hline Abdomen & . & . & $0.882 \times 0.718$ & . & $\mathrm{I} \cdot 027 \times 0.782$ \\
\hline $\mathrm{L}: \mathrm{B}$ of pre-c & antennal & . & I $: 2 \cdot 37$ & . & I $: 2 \cdot 55$ \\
\hline $\mathrm{L}: \mathrm{B}$ of hind & head & . & I : $\mathbf{I} \cdot 83$ & . & $I: I \cdot 9 I$ \\
\hline Cephalic inde & ex & . & I : I I I 2 & . & $\mathrm{I}: \mathrm{I} \cdot \mathrm{I} 8$ \\
\hline
\end{tabular}

MATERIAL EXAmined. Forty males and 60 females from Corvus corone cornix Linn. from South and North Uist, Norfolk, Mull, Dublin, Estonia and Sweden. Neotype (male), neallotype (female) from Corvus corone cornix Linn. from South Uist, Scotland in Meinertzhagen collection (British Museum (Nat. Hist.)), on slide no. 35. Neoparatypes : 39 males and 59 females from the same host (data above).

Eight males and 9 females from Corvus corone sardonius Klein. from Egypt, Sardonia, and Palestine are not separable from the above specimens.

\section{Brïelia uncinosa plena subsp. $\mathrm{n}$.}

Fifteen males and 44 females from Corvus corone corone Linn. from Devon, England were found to differ from typical uncinosa in the pattern of the abdominal tergal plates. In those specimens instead of the tergal plates resembling a horizontallylaid sign of interrogation, the hook of the sign in the majority of plates is closed leaving a circular unpigmented area. Apart from this one constant difference no other reliable character could be found to differentiate the two forms, these specimens are, therefore, treated as a subspecies of uncinosa.

Material EXAmined. Fifteen males and 44 females from Corvus corone corone from Devon. Holotype (male), allotype (female) from Corvus corone corone Linn. from Devon on slide no. $\mathrm{I}_{5262}$ in Meinertzhagen collection (British Museum (Nat. Hist.)). Paratypes: I4 males and 43 females from the same host (data above).

\section{Brïelia saliemi sp. nov.}

(Text-figs. I6, 40-4I, 92-96)

This species is similar to Brüelia uncinosa (Burmeister) from which it can be easily distinguished by the shape of the head, abdominal chaetotaxy and shape of the tergal plates. This species is also allied to B. saliemi mollii subsp. nov. from which it can be separated by the tergal plates of the female.

MALE. Head as long as broad. Marginal carina entire dorsally but feebly sclerotized and depressed in the middle. Dorsal suture present, not continued across the head. Ventral carina comparatively less sclerotized and fused to the ends of marginal 
A REVISION OF THE BRÜLLA (MALLOPHAGA) SPECIES

carina. Tergal plates triangular, approximate, with scooped out areas in the anterior region, while continuously sclerotized posteriorly. Genitalia of the pattern seen in $B$. uncinosa and distinguished by the characters of parameres, endomeres and mesosome. Parameres are short with broader head.
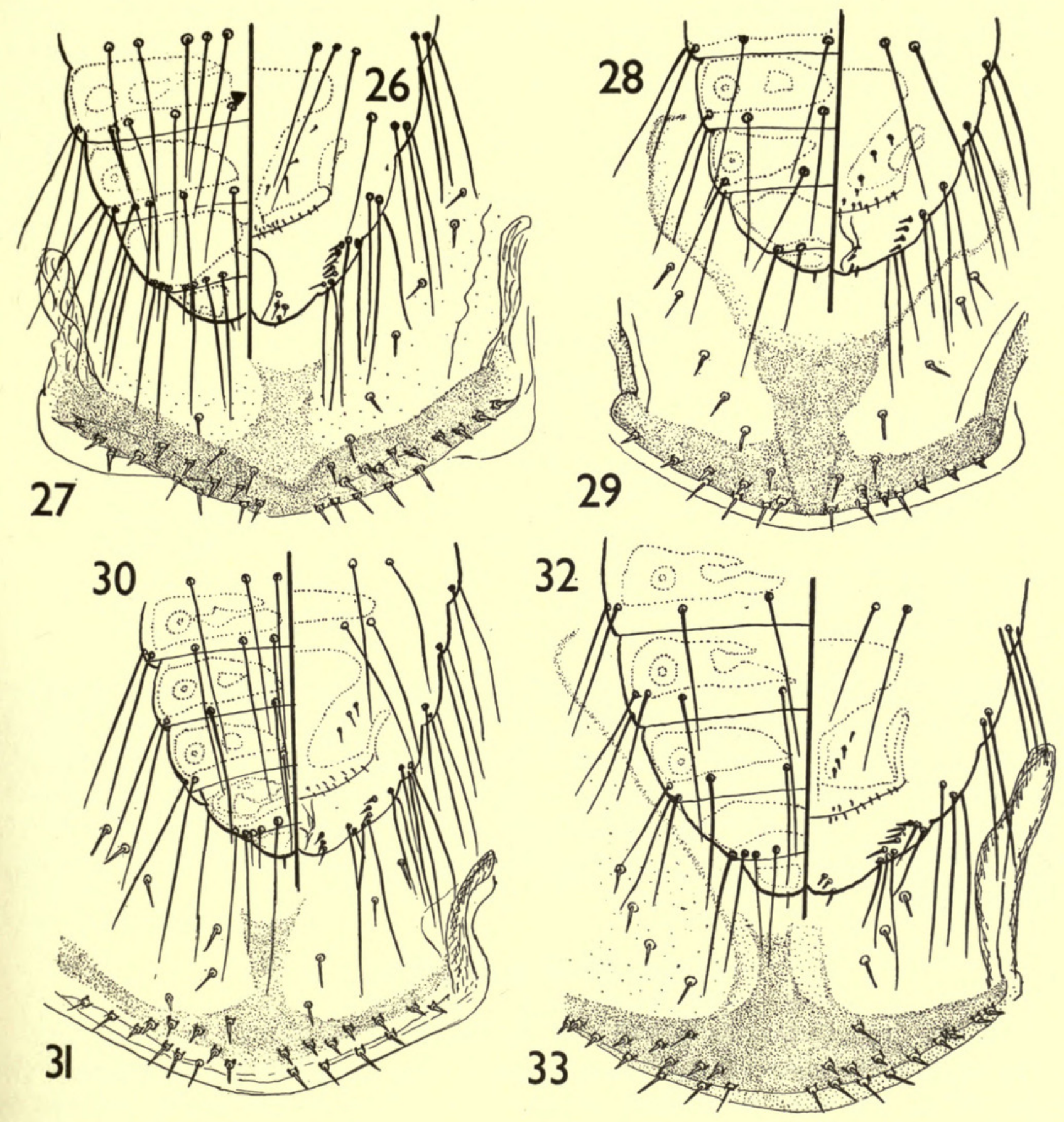

Figs. 26-33. Last abdominal segments and vulvar chaetotaxy of adult females : (26-27) Brüelia leucocephalus (Nitzsch); (28-29) Brüelia theresae sp. nov. ; (30-3I) Brüelia quadrangularis (Rudow); (32-33) Brüelia tasniemae sp. nov.

Female. Similar to the male but tends to be larger. The tergal, sternal and genital plates are different from the allied forms. The abdominal chaetotaxy tends to be scarce in this species. 


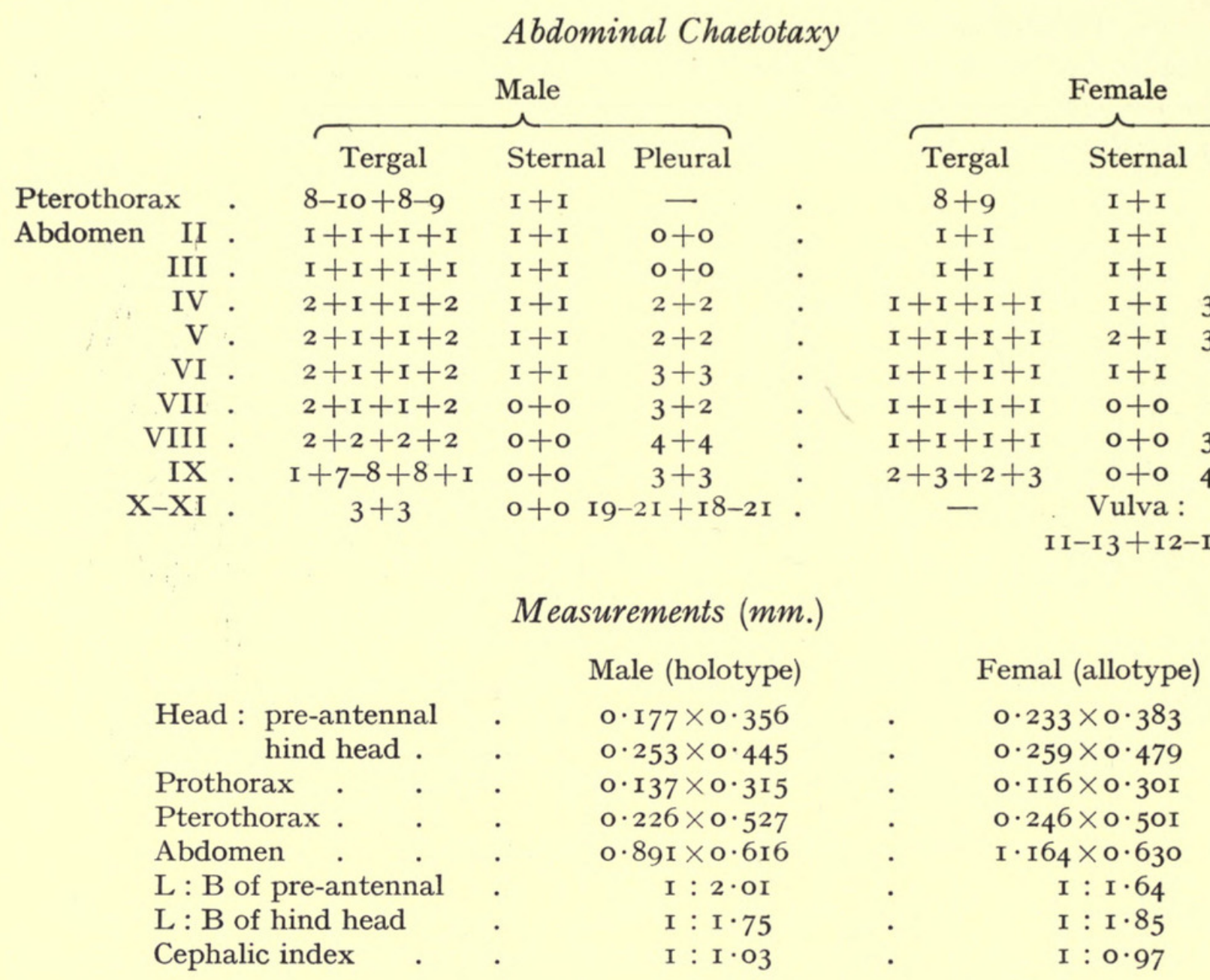

Material EXamined. Ten males and 28 females from Corvus splendens Vieill. from Bihar, Deccan, Lyallpur and Nepal. Holotype (male) and allotype (female) on slide no. 9313 from Corvus splendens in Meinertzhagen collection (British Museum (Nat. Hist.)). Paratypes : 9 males and 27 females from the same host (data above).

One male and 3 females from Corvus splendens zugmeyeri, from Sind in the British Museum (Nat. Hist.) collection, were found to be indistinguishable from the specimens referred to above.

\section{Brïelia saliemi mollii subsp. nov.}

(Text-figs. I7, 42-43, 97-IOo)

This species is similar to the above species, but is easily distinguished by the tergal plates. Plates II-VIII have circular, colourless stigmatal spots, while in the allied form these plates are open like a beak in the anterior region. In female the tergal plates are triangular and entire.

MALE. Marginal carina well developed, indented in the middle, pigmentation light. Ventral carina well developed; devoid of pigment. Tergal plates II-VI more or less rectangular with two clear circular areas, VII-VIII triangular, IX very narrow and acutely triangular. Genital armature as shown in figures, it is distinguished from allied species by the mesosomal plate. 
Female. Similar to the allied species in general characters. Tergal plates rectangular. Genital plate triangular, terminal angle not very acute.

\section{Abdominal Chaetotaxy}

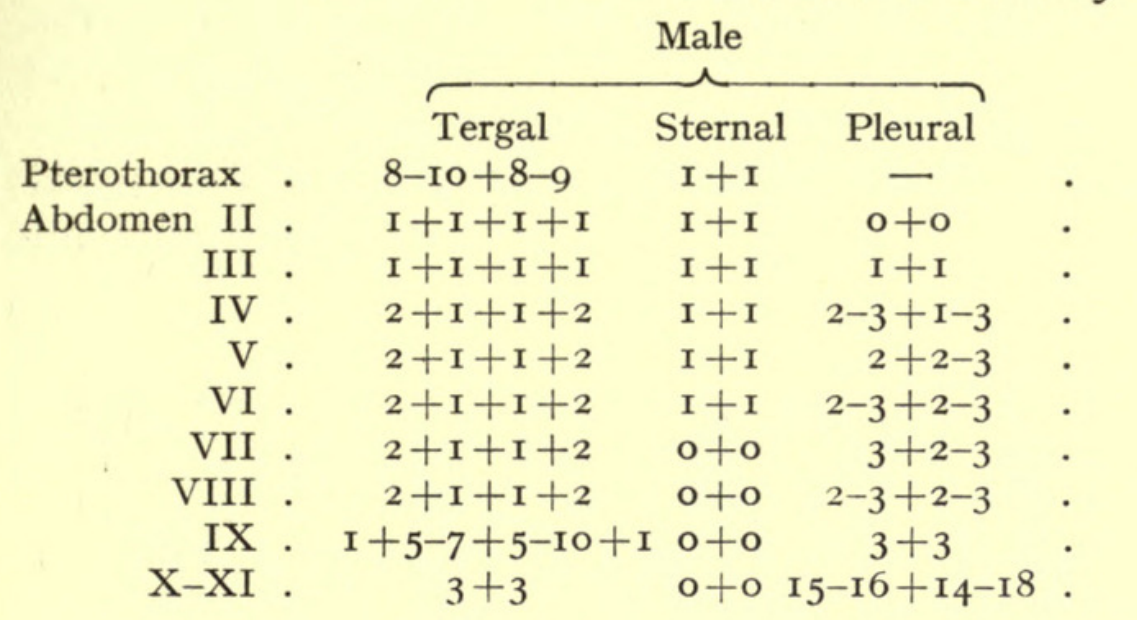

\section{Measurements $(\mathrm{mm}$.}

$\begin{array}{llc} & & \text { Male (holotype) } \\ \text { Head : pre-antennal } & . & 0.177 \times 0.369 \\ \text { hind head . } & . & 0.253 \times 0.465 \\ \text { Prothorax . } & . & 0.103 \times 0.288 \\ \text { Pterothorax } . \quad . & . & 0.17 \mathrm{I} \times 0.479 \\ \text { Abdomen . } & . & 0.82 \mathrm{I} \times 0.6 \mathrm{I} 6 \\ \text { L : B of pre-antennal } & . & \mathrm{I}: 2.08 \\ \text { L: B of hind head } & . & \mathrm{I}: \mathrm{I} \cdot 83 \\ \text { Cephalic index } & . & \mathrm{I}: \mathrm{I} \cdot \mathrm{0} 8\end{array}$

\begin{tabular}{|c|c|c|}
\hline \multicolumn{3}{|c|}{ Female } \\
\hline Tergal & Sternal & Pleural \\
\hline $7-9+8-9$ & $I+I$ & 一 \\
\hline $\mathbf{I}+\mathbf{I}$ & $I+I$ & $0+0$ \\
\hline $\mathbf{I}+\mathbf{I}$ & $I+I$ & $\mathbf{I}+\mathbf{I}$ \\
\hline $\mathbf{I}+\mathbf{I}+\mathbf{I}+\mathbf{I}$ & $\mathbf{I}+\mathbf{I}$ & $2+2-3$ \\
\hline $\mathbf{I}+\mathbf{I}+\mathbf{I}+\mathbf{I}$ & $\mathbf{I}+\mathbf{I}$ & $2-3+2-3$ \\
\hline $\mathbf{I}+\mathbf{I}+\mathbf{I}+\mathbf{I}$ & $I+I$ & $2-3+3-4$ \\
\hline $\mathbf{I}+\mathbf{I}+\mathbf{I}+\mathbf{I}$ & $o+o$ & $2-3+3$ \\
\hline$I+I$ & $o+o$ & $3-4+3-4$ \\
\hline $3+3$ & $0+0$ & $4+3-4$ \\
\hline 一 & $\begin{array}{l}\text { Vulva: } \\
-I_{5}+I_{1}\end{array}$ & 一 \\
\hline
\end{tabular}

Female (allotype)

$$
\begin{aligned}
& 0.219 \times 0.43 \mathrm{I} \\
& 0.274 \times 0.5 \mathrm{I} 4 \\
& 0.103 \times 0.321 \\
& 0.198 \times 0.514 \\
& 0.061 \times 0.596 \\
& \text { I : } 1 \cdot 96 \\
& \text { I : } \mathbf{I} \cdot 87 \\
& \text { I : I } 04
\end{aligned}
$$

Material EXAmined. Five males and 4 females from Corvus coronoides macrorhynchus Wagler from Malay Peninsula, 4 males and II females from Corvus c. intermedius Adams from Bihar (India), I male and 5 females from Corvus c. colonorum Swinhoe from China, I male from Corvus $c$. insularis Heinroth and 2 males from Corvus c. bennetti North. Holotype (male) and allotype (female) from Corvus coronoides macrorhynchus Wagler from Malay Peninsula, in Meinertzhagen collection (British Museum (Nat. Hist.)), on slide no. 4022. Paratypes : 4 males and 3 females from the same host (data above).

Brïelia atherae sp. nov.

(Text-figs. I8, 44-45, IOI-I04)

This species is closely allied to Brüelia varia from which it can be distinguished by the shape of the head and tergal plates. The male genitalia exhibit characteristic mesosomal characters.

Male. Marginal carina entire, backwardly hanging to form a concave hyaline margin in the middle. Preocular and postocular nodus well developed. Ventral carina sclerotized only proximally. Tergal plates II-IX approximate, III-IX triangular with one circular and irregular clear area. Sternal plates III-VI well formed. Genital armature of the type found in B. varia, but differs in details of proximal heads of the parameres. Mesosomal plates as shown in the figure.

Female. Similar to the male except for abdominal chaetotaxy. 


\section{Measurements (mm.)}

\begin{tabular}{|c|c|c|c|c|c|}
\hline \multirow{3}{*}{\multicolumn{2}{|c|}{$\begin{aligned} & \text { Head : } \text { pre-antennal } \\
& \text { hind head . }\end{aligned}$}} & \multicolumn{3}{|c|}{ Male (holotype) } & \multirow{2}{*}{$\begin{array}{c}\text { Female (allotype) } \\
0.253 \times 0.486\end{array}$} \\
\hline & & 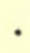 & $0.239 \times 0.424$ & . & \\
\hline & & - & $0.28 \mathrm{I} \times 0.52 \mathrm{I}$ & . & $0.308 \times 0.568$ \\
\hline Prothorax & . & . & $0.123 \times 0.328$ & . & $0.103 \times 0.342$ \\
\hline erothorax & . & . & $0.184 \times 0.45^{2}$ & . & $0.212 \times 0.547$ \\
\hline domen & . & . & $I \cdot I 84 \times 0.685$ & . & $\mathrm{I} \cdot 54 \mathrm{I} \times 0.788$ \\
\hline B of pre-c & nal & . & I $: \mathbf{I} \cdot 77$ & . & I $: I \cdot 92$ \\
\hline of hind & & . & I $: I \cdot 85$ & . & I $: I \cdot 84$ \\
\hline halic inde & . & . & I : I $\cdot 00$ & . & $\mathrm{I}: \mathrm{I} \cdot \mathrm{O} 4$ \\
\hline
\end{tabular}
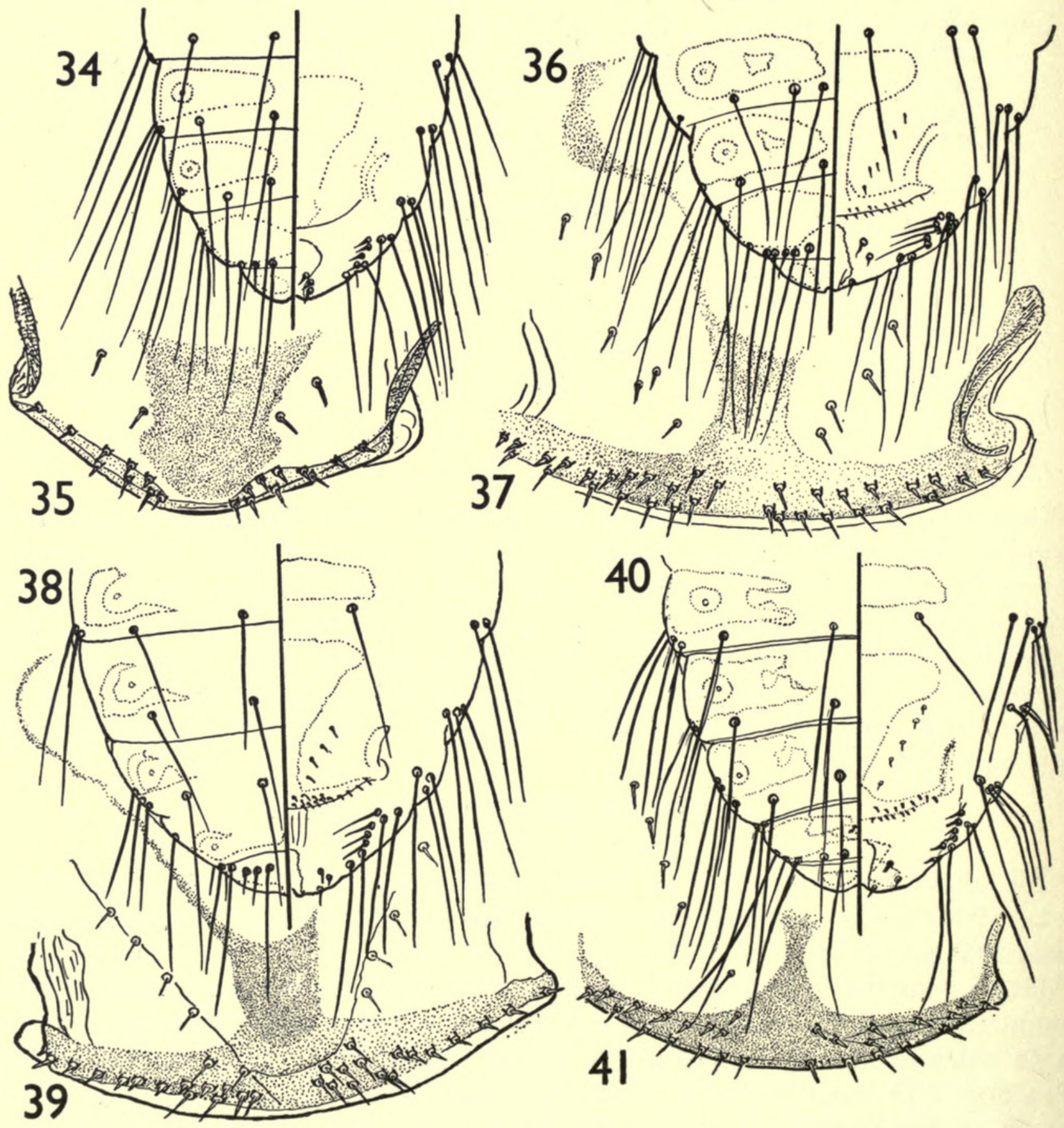

FIgs. 34-4I. Last abdominal segments and vulvar chaetotaxy of adult females (34-35) Brüelia variegata sp. nov.; (36-37) Brüelia afzali sp. nov. ; (38-39) Brüelia; uncinosa (Burmeister); (40-4I) Brüelia saliemi sp. nov. 
A REVISION OF THE BRÜELLA (MALLOPHAGA) SPECIES

Material EXAmined. Thirty-four males and 30 females from Corvus corax laurencei Hume from Shibar Pass, Afghanistan. Holotype (male), allotype (female) from Corvus corax laurencei Hume on slide no. 9765 in Meinertzhagen collection (British Museum (Nat. Hist.)). Paratypes: 33 males and 29 females from the same host (data above).

Twenty males and 6 females from Corvus corax ruficollis Lesson from Port Sudan, Ahaggar, Ashaira, Palestine and Egypt, were found to be indistinguishable from the above specimens.

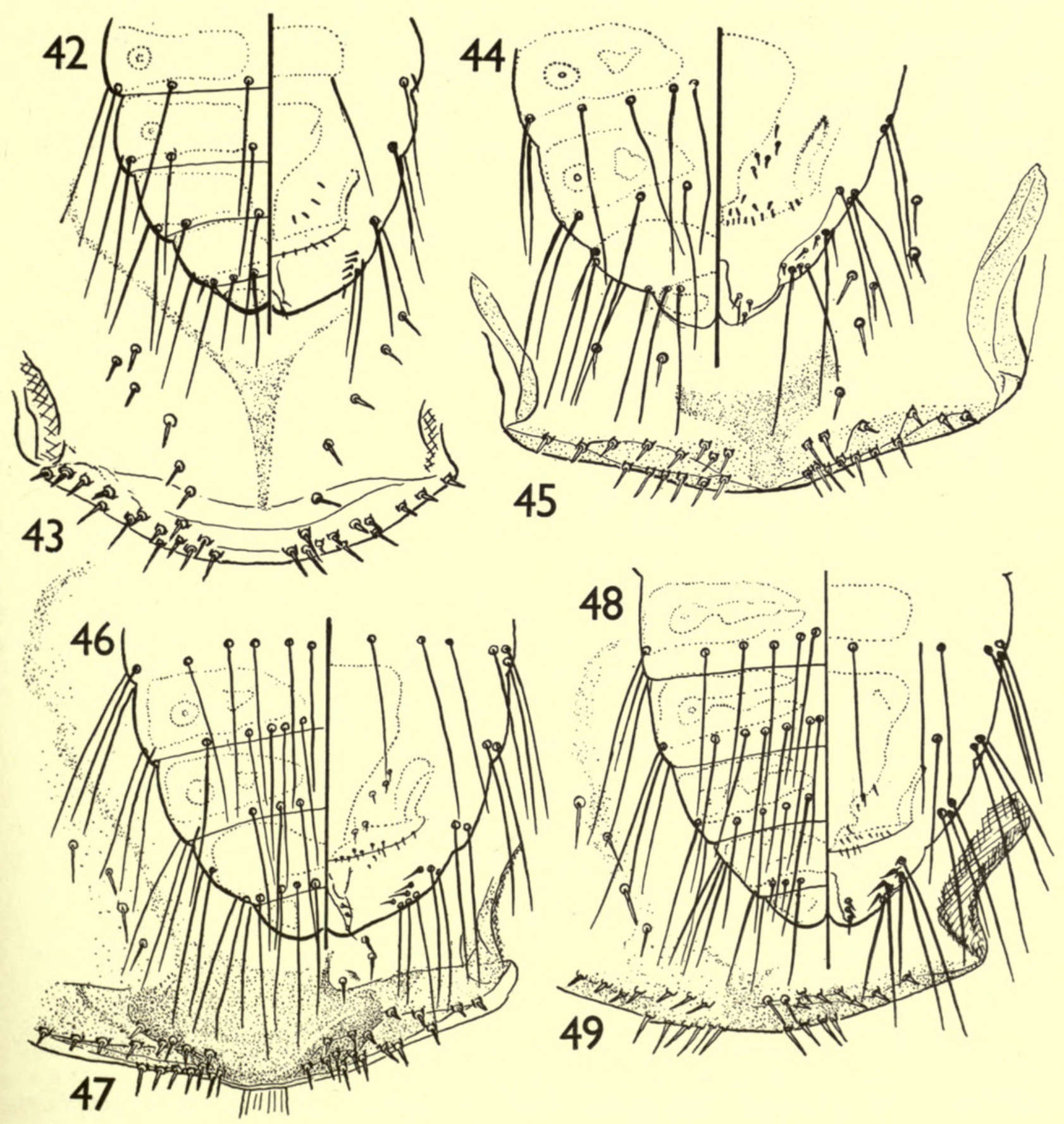

FIgs. 42-49. Last abdominal segments and vulvar chaetotaxy of adult females; (42-43) Brüelia saliemi mollii ssp. nov. ; (44-45) Brüelia atherae sp. nov. ; (46-47) Brüelia cryptoleucus sp. nov. ; (48-49) Brüelia varia (Burmeister). 
Brïelia cryptoleucus sp. nov.

(Text-figs. I9, 46-47, I05-108)

This species resembles Brïelia varia, B. atherae and B. nawabi sp. nov. From all the three, it can be distinguished by (I) the shape of the head, (2) marginal carina, (3) tergal plates in male, (4) shape of the female genital plate. The male genital armature is similar to $B$. atherae from which it can be distinguished by the size of the parameres, which are short and narrow with a simple proximal head. The basal plate is also very narrow.

The abdominal chaetotaxy in this species is also a characteristic feature. The female genital plate differs from all the other species in its shape and marginal chaetotaxy. The ventral hairs on abdominal segment IX are almost double the size found in other species.

Marginal carina, ventral carina, preocular nodus and pre-antennal nodus are well developed.



Pterothorax

$$
8-9+8-9
$$$$
\mathbf{I}+\mathbf{I}
$$

$\overbrace{\text { Tergal }}^{\text {Female }}-\underbrace{\text { Feural }}_{\text {Sternal Pleural }}$

Abdomen :

$\begin{array}{rcc}\text { II } & \cdot & \mathrm{I}+3+3+\mathrm{I} \\ \mathrm{III} & \cdot & \mathrm{I}+4+4+\mathrm{I} \\ \mathrm{IV} & \cdot & \mathrm{I}+4+4+\mathrm{I} \\ \mathrm{V} & \cdot & \mathrm{I}+4+4+\mathrm{I} \\ \mathrm{VI} & \cdot & \mathrm{I}+4+4+\mathrm{I} \\ \mathrm{VII} & \cdot & \mathrm{I}+5+5+\mathrm{I} \\ \mathrm{VIII} & \cdot & \mathrm{I}+4+4-5+\mathrm{I} \\ \mathrm{IX} & \cdot & 5+3+3+6 \\ \mathrm{X}-\mathrm{XI} & \cdot & 3+3\end{array}$

$\begin{array}{ccc}\mathrm{I}-2+\mathrm{I}-2 & \mathrm{O}+\mathrm{O} \\ \mathrm{I}-2+\mathrm{I}-2 & \mathrm{I}-2+\mathrm{I}-2 & . \\ \mathrm{I}-2+\mathrm{I}-2 & 2+2 & . \\ \mathrm{I}-2+\mathrm{I}-2 & 2+\mathrm{I} & . \\ \mathrm{I}-2+\mathrm{I}-3 & 3+3 & . \\ \mathrm{O}+\mathrm{O} & 3+3 & . \\ \mathrm{O}+\mathrm{O} & 3-4+2-4 \\ \mathrm{O}+\mathrm{O} & 2-3+3-4 \\ \mathrm{O}+\mathrm{O} & \mathrm{I} 3-\mathrm{I} 4+\mathrm{I} 2-\mathrm{I} 4\end{array}$

$$
9+\text { ro }
$$$$
\mathrm{I}+\mathrm{I}
$$

$$
\begin{aligned}
& \mathrm{I}+3+2+\mathrm{I} \\
& \mathrm{I}+4+4+\mathrm{I}
\end{aligned}
$$$$
\mathrm{I}+4+5+\mathrm{I}
$$$$
\mathrm{I}+4-5+5+\mathrm{I}
$$$$
\mathrm{I}+4+4+\mathrm{I}
$$$$
\mathrm{I}+4+4+\mathrm{I}
$$$$
\mathrm{I}+3+3-4+\mathrm{I}
$$$$
4+4
$$$$
4+4
$$$$
5+4
$$$$
4+4
$$$$
4+4
$$$$
3+3
$$$$
\mathrm{o}+\mathrm{o}
$$$$
\mathrm{o}+\mathrm{o}
$$$$
\mathrm{o}+\mathrm{o}
$$$$
\text { Vulva : }
$$$$
\mathrm{I} 2+\mathrm{I} 2-\mathrm{I} 3
$$

\section{Measurements (mm.)}

$\begin{array}{lll}\text { Head : pre-antennal } & . & 0.226 \times 0.424 \\ \text { hind head } . & . & 0.30 \mathrm{I} \times 0.534 \\ \text { Prothorax . } & . & 0 . \mathrm{I} 3 \mathrm{I} \times 0.3 \mathrm{I} 5 \\ \text { Pterothorax . } & . & 0 . \mathrm{I} 84 \times 0.466 \\ \text { Abdomen . } & . & \mathrm{I} \cdot 062 \times \cdot 0753 \\ \text { L : B of pre-antennal } & . & \mathrm{I}: \mathrm{I} \cdot 87 \\ \text { L : B of hind head } & . & \mathrm{I}: \mathrm{I} \cdot 77 \\ \text { Cephalic index } & . & \mathrm{I}: \mathrm{I} \cdot \mathrm{OI}\end{array}$

\section{Male (holotype)}

$$
\begin{array}{r}
\mathrm{O} \cdot 226 \times 0.424 \\
\mathrm{O} \cdot 3 \mathrm{OI} \times 0.534 \\
\mathrm{O} \cdot \mathrm{I} 3 \mathrm{I} \times \mathrm{O} \cdot 3 \mathrm{I} 5 \\
\mathrm{O} \cdot \mathrm{I} 84 \times 0.466 \\
\mathrm{I} \cdot \mathrm{O} 62 \times \mathrm{O} \times \mathrm{O} 753 \\
\mathrm{I}: \mathrm{I} \cdot 87 \\
\mathrm{I}: \mathrm{I} \cdot 77 \\
\mathrm{I}: \mathrm{I} \cdot \mathrm{OI}
\end{array}
$$

Female (allotype)

$$
\begin{array}{r}
0.238 \times 0.493 \\
0.315 \times 0.589 \\
0.123 \times 0.356 \\
0.2 \text { I } 2 \times 0.56 I \\
I \cdot 205 \times 0.794 \\
\text { I }: 2.06 \\
\text { I }: I .87 \\
\text { I }: I .06
\end{array}
$$

Material examined. Six males and I2 females from Corvus cryptoleucus from Texas and Illinois. Holotype (male) and allotype (female) from Corvus cryptoleucus Couch from Texas on slide no. 46 in Meinertzhagen collection (British Museum (Nat. Hist.)). Paratypes : 5 males and II females from the same host (data above). 

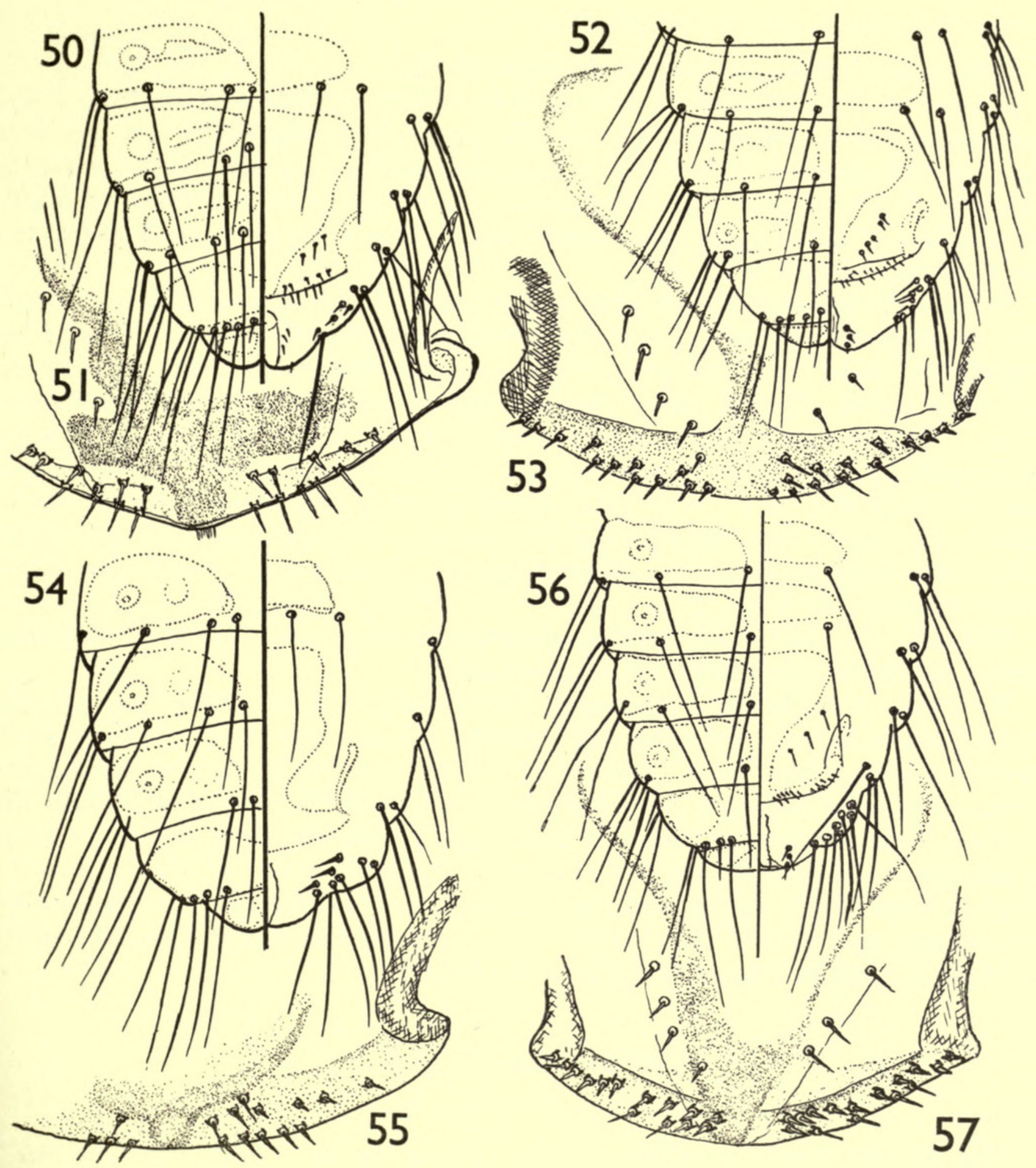

FIGs. 50-57. Last abdominal segments and vulvar chaetotaxy of adult females; (50-5I) Brüelia nawabi sp. nov.; (52-53) Brüelia perwienae sp. nov.; (54-55) Brüelia bipunctata (Rudow); (56-57) Brüelia latifasciata (Piaget). 
Brüelia varia (Burmeister), I838

(Text-figs. 20, 48-49, I09-II3)

Nirmus varia Burmeister, 1838, Handb. Ent. $2: 430$.

Type host : Corvus monedula spermologus Vieillot.

Burmeister (1838) described Brüelia varia from material collected from Corvus corone and Corvus monedula. Giebel (I86I and $\mathrm{I} 874$ ) referred to this species all the material obtained from Corvus corone, Corvus frugilegus and Corvus monedula. Hopkins \& Clay (I952) have designated Corvus monedula spermologus Vieillot as type host of the species under consideration. It is a narrow headed species with the following characters :

MALE. Pre-antennal region long and narrow. Marginal carina entire dorsally and interrupted ventrally and feebly sclerotized medially. Preocular nodus well pigmented, fused with the pre-antennal nodus. Postocular nodus running into preocular nodus. Ventral carina well developed and continuous with the marginal carina. Tergal plates II-IX well formed, narrow, triangular, sloping obliquely downwards in the middle to resemble the tegmina of a katytid: II-VI opening like the beak of a bird; VII-VIII triangular, each with two uncoloured circular areas ; IX entire ; Sternal plates II-VI transverse. Genitalia as shown in the figures. Basal plate twice as long as the parameres and its distal breadth. Parameres narrow, with characteristic head.

Female. Similar to male but the measurements are greater. Antennae, abdominal plates and chaetotaxy exhibit sexual dimorphism.

MATERIAL EXAMINED. Five males and 7 females from Corvus m. monedula from Sweden, Estonia, Salonika and Croatia ; 5 males and I3 females from Corvus monedula soemoeringii from Afghanistan. Twenty-six males and 32 females from Corvus frugilegus frugilegus from Norfolk, Cornwall, Wilts., Hants and South Uist, Ireland, Orkney, Cumberland; 2 males and 2 females from Corvus frugilegus pastinator Gould from China; 9 males and 4 females from Corvus frugilegus tschusii Hartert from Lyallpur (Pakistan), and I5 males and 44 females from Corvus corone corone Linn. and 8 males from Corvus corone orientalis Eversmann from Afghanistan were found to be indistinguishable from this species.

\section{Brïelia nawabi sp. nov.}

(Text-figs. 2I, 50-5I, II4-II7)

This species closely resembles Brïelia atherae sp. nov. from which it can be distinguished by the shape of the head and the development of the marginal and ventral carina.

MaLE. Head as long as broad. Fore head twice as broad as long. Marginal carina very narrow, entire dorsally, with a slight median depression, and interrupted ventrally. Preocular nodus well developed but not reaching as far as the preantennal nodus. Postocular nodus and marginal temporal carina well formed. Tergal plates well formed, approximate, II-VI interrupted in the middle, VII-XI triangular, 

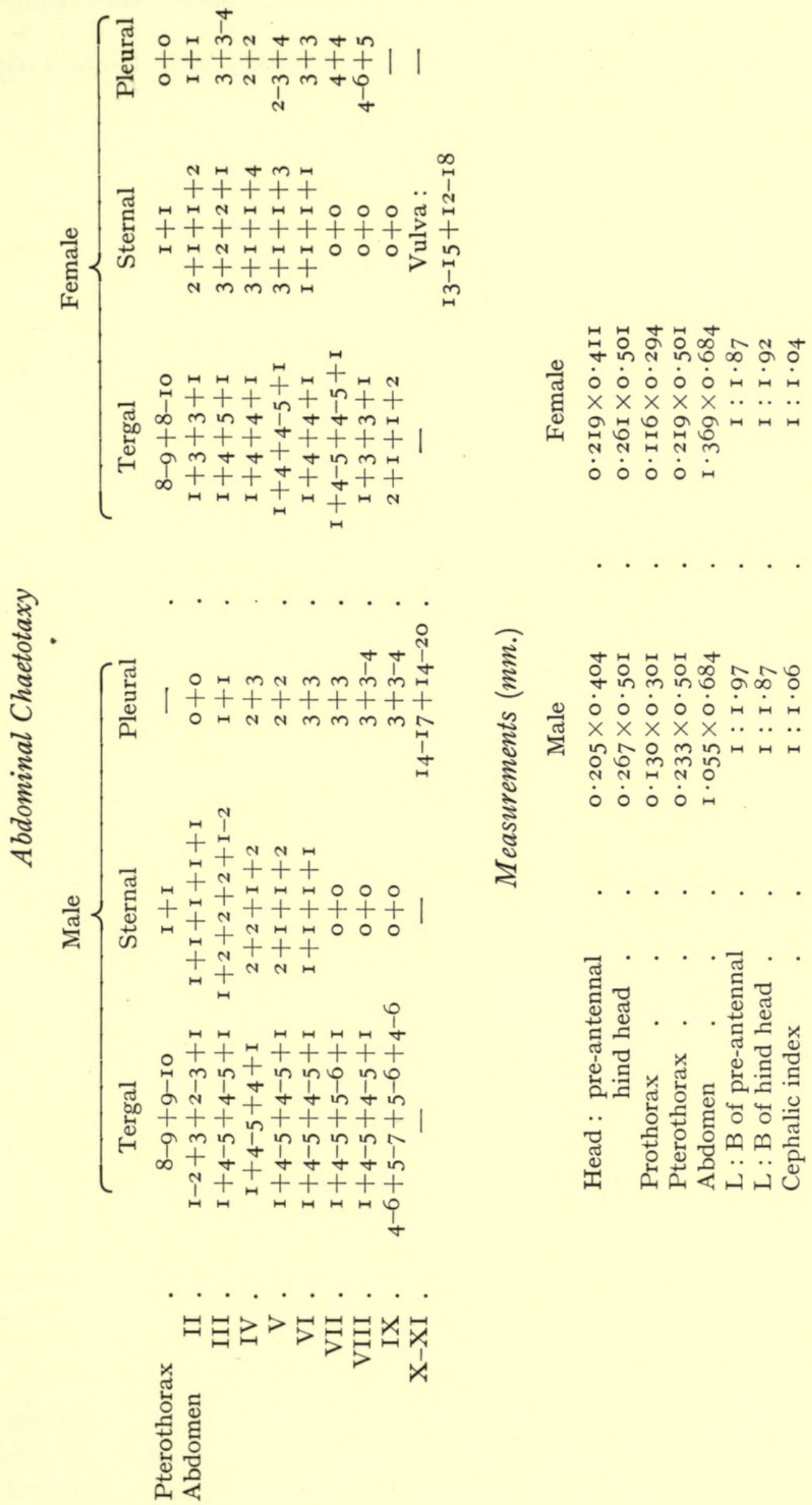
entire. Male genital armature as shown in the figure. Basal plate comparatively shorter than in other species of the same group,

Female. Similar to the male, but differs considerably in abdominal chaetotaxy and tergal plates.

\section{Abdominal Chaetotaxy}

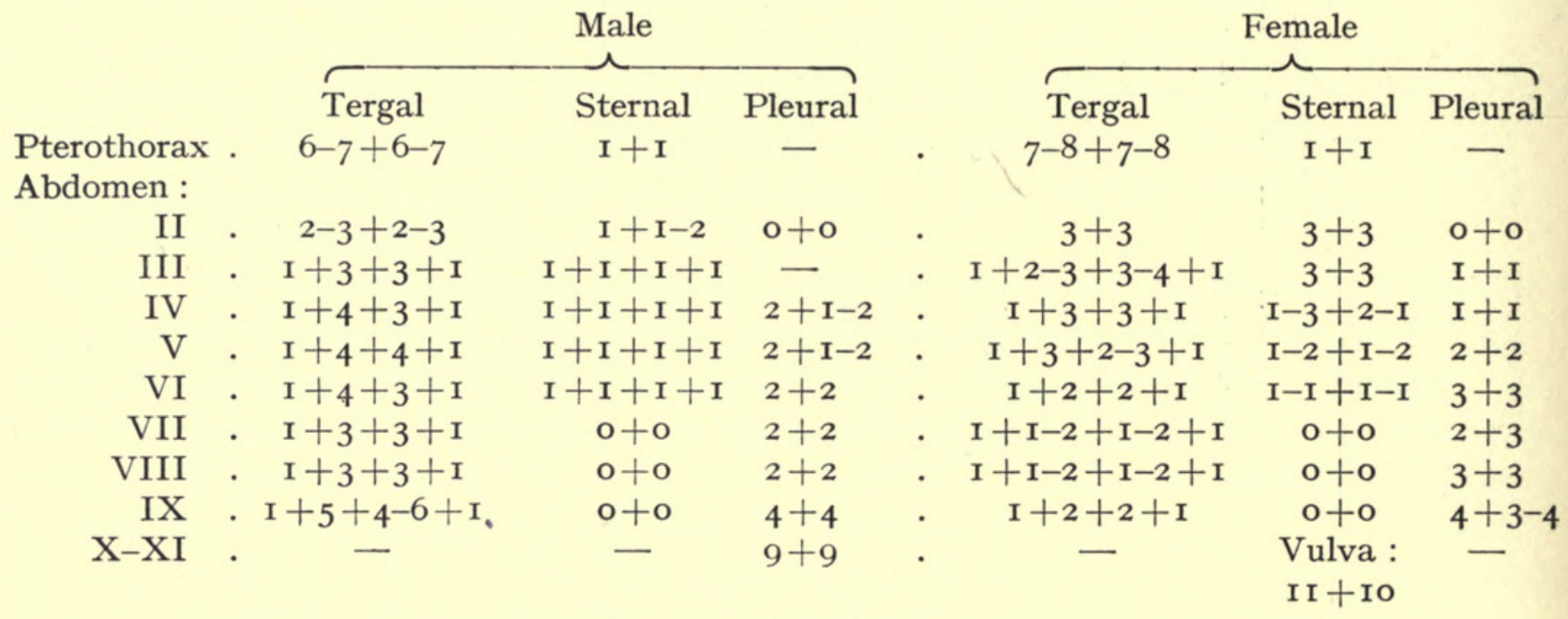

\section{Measurements (mm.)}

\begin{tabular}{|c|c|c|c|c|c|}
\hline \multirow{3}{*}{\multicolumn{2}{|c|}{$\begin{aligned} \text { Head : pre-antennal } \\
\text { hind head . }\end{aligned}$}} & \multicolumn{3}{|c|}{ Male (holotype) } & \multirow{2}{*}{$\begin{array}{c}\text { Female (allotype) } \\
0.260 \times 0.493\end{array}$} \\
\hline & & ${ }^{\circ}$ & $0.219 \times 0.43^{8}$ & - & \\
\hline & & . & $0.260 \times 0.479$ & . & $0.28 \mathrm{I} \times 0.547$ \\
\hline Prothorax & . & . & $0.109 \times 0.253$ & . & $0.137 \times 0.294$ \\
\hline Pterothorax & . & . & $0.164 \times 0.397$ & . & $0.171 \times 0.45^{2}$ \\
\hline Abdomen & . & . & $\mathrm{I} \cdot \mathrm{I} 64 \times 0.637$ & . & $\mathrm{I} \cdot 377 \times 0 \cdot 788$ \\
\hline $\mathrm{L}: \mathrm{B}$ of pre- & antennal & . & I $: 2 \cdot 0$ & . & I : $\mathbf{I} \cdot 89$ \\
\hline L : B of hind & head & - & I $: I \cdot 84$ & - & I : $I \cdot 94$ \\
\hline Cephalic ind & ex & . & I $: \mathbf{I} \cdot \mathrm{O}$ & . & I $: I \cdot O$ \\
\hline
\end{tabular}

Material examined. One male and 4 females from Corvus capensis from South West Africa, Damaraland. Holotype (male), allotype (female) from Corvus capensis Licht. from South West Africa, slide no. I3469 in Meinertzhagen collection (British Museum (Nat. Hist.)). Paratypes : 3 females from the same host (data above).

\section{Brüelia perwienae sp. nov.}

(Text-figs. 22, 52-53, II $8-122$ )

The specimens referred to this name resemble Brïelia argula (Burmeister) in all superficial details, but differ in the male genitalia and in the abdominal chaetotaxy of the female. It may also be confused with Brïelia varia (Burmeister), but can be separated by the proportions of the parameres and abdominal chaetotaxy.

MALE. Pre-antennal region triangular, fore head truncate. Marginal carina well developed, slightly depressed in the middle, entire dorsally and interrupted ventrally. Preocular nodus well developed. Postocular nodus wanting. Tergal 

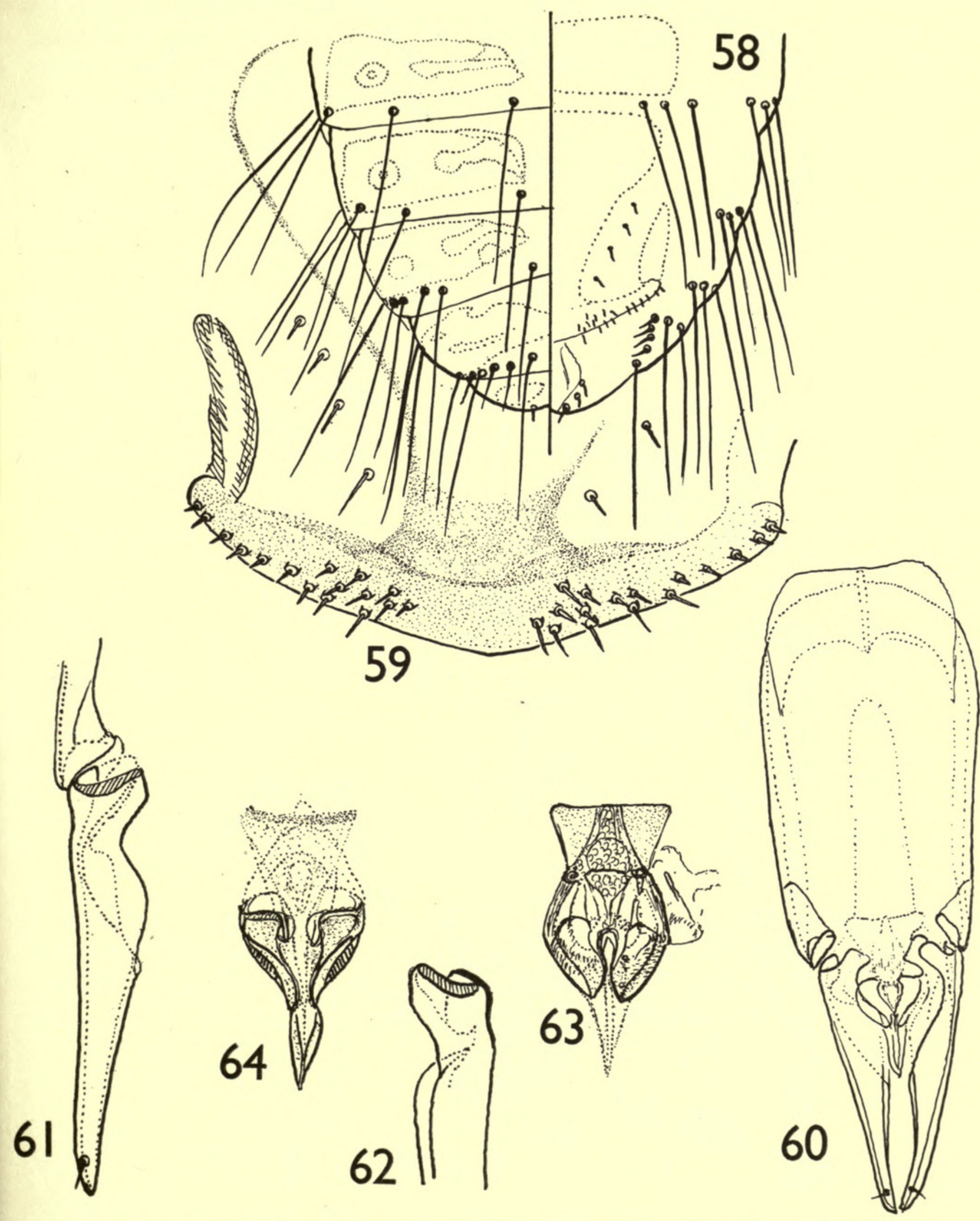

FIGs. 58-64. (58-59) last abdominal segments of adult female Brüelia rotundata (Osborn) and vulvar chaetotaxy of the same; (6o-64) male genital armature of Brüelia argula (Burmeister): (6o) genitalia, (6I) parameres, (62) proximal head of parameres, (63-64) two different views of mesosomal plate. 


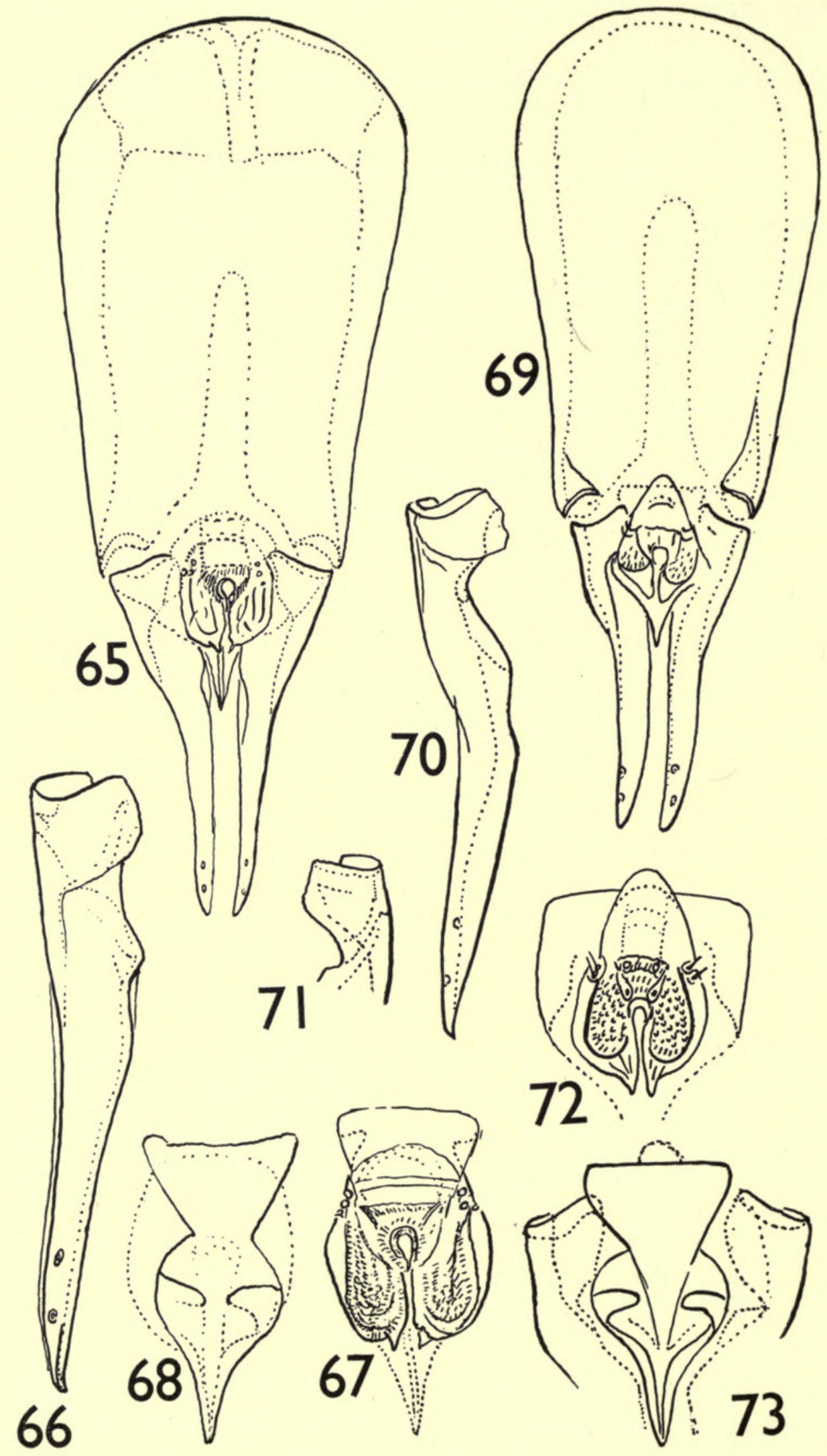

FIGs. 65-73. Male genital armatures: (65-68) Brüelia leucocephalus (Nitzsch) : (65) genitalia, (66) parameres, (67-68) different views of mesosomal plate; (69-73) Brüelia theresae sp. nov.: (69) genitalia, (70) parameres, (7I) proximal head of parameres, (72-73) two different aspects of mesosomal plate. 
plates well developed, II-VIII wedge-shaped, IX triangular. Parameres about one-quarter of the total length of the genital armature. The details of the proximal head of the parameres are of specific value and shown in the figure. Female similar to the male, although exhibiting sexual dimorphism of antennae and differences in the abdominal chaetotaxy.

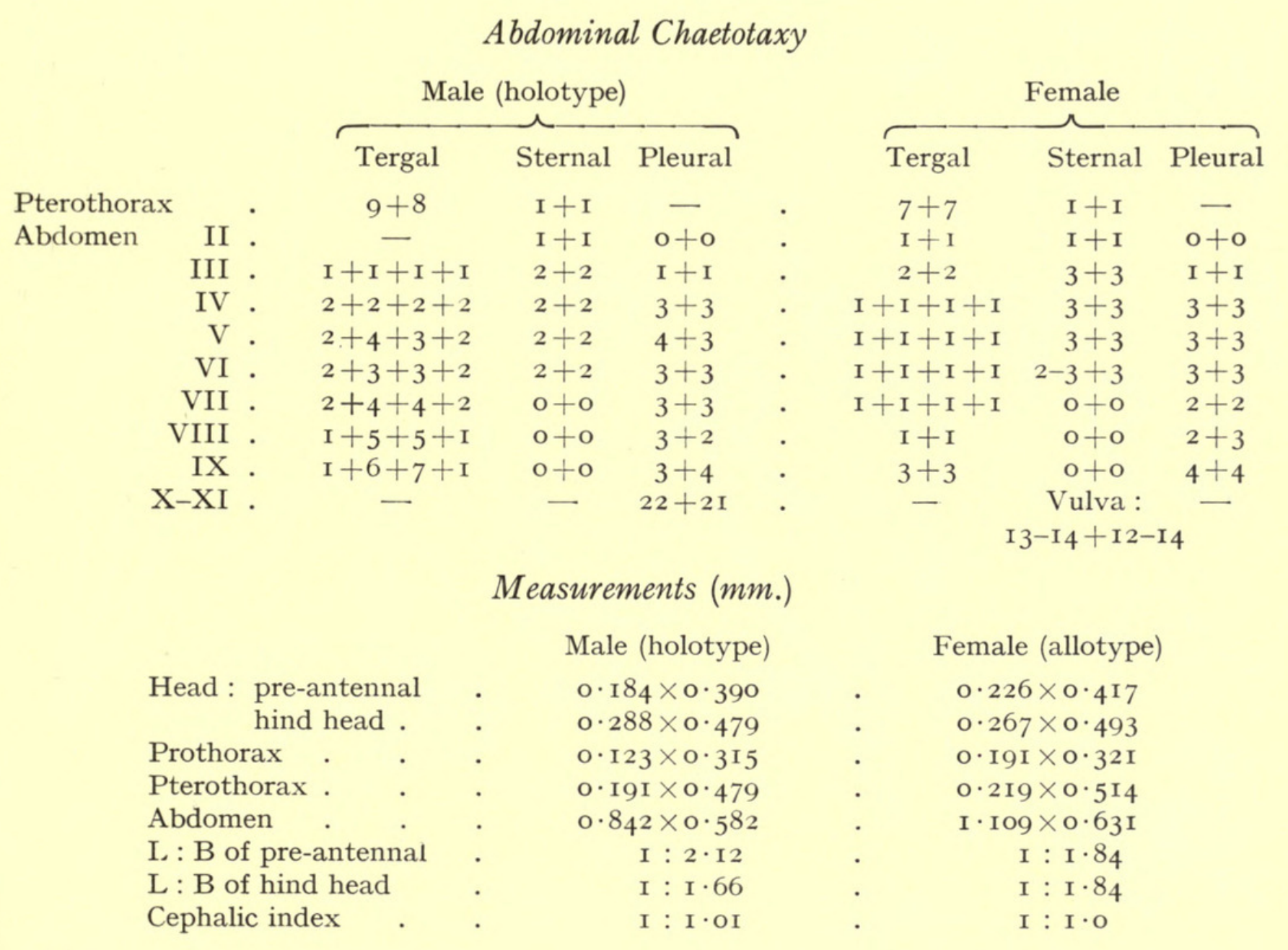

Material examined. One male and 5 females from Corvus nasicus from Cuba. Holotype (male) and allotype (female) from Corvus nasicus Temminck from Cuba on slide no. 50 and 12669 respectively in Meinertzhagen collection (British Museum (Nat. Hist.)). Paratypes : 4 females from the same host (data above).

\section{Brïelia bipunctata (Rudow), I 870}

(Text-figs. 23, 54-55)

Nirmus bipunctata Rudow, I870, Z. ges. Nat. Wiss. $35: 467$.

Type host : Corvus albus Müller.

As stated above, Hopkins \& Clay in an unpublished account have shown that this name is not a nomen novum for Brüelia quadrangularis and that the description 

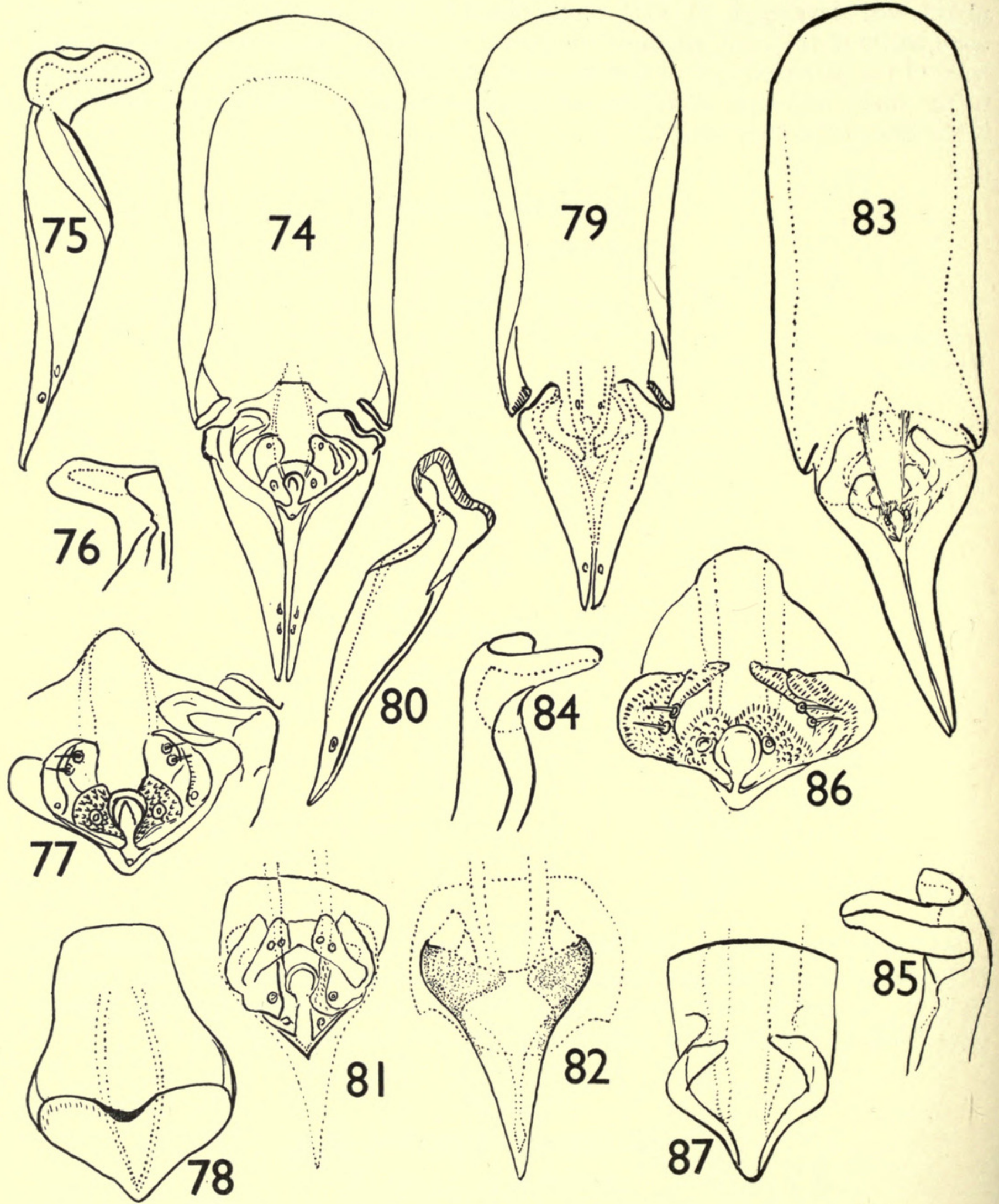

Figs. 74-87. Male genital armatures: $(74-78)$ Brüelia tasniemae sp. nov. : (74) genitalia, (75) paramere, $(76)$ proximal head of paramere, $(77-78)$ two views of mesosomal plate; (79-82) Brüelia variegata sp. nov. : (79) genitalia, (8o) paramere, (8I-82) two different views of mesosomal plate; $(83-87)$ Brüelia afzali sp. nov. ; (83) genitalia, $(84-85)$ two views of the proximal head of paramere, (86-87) two different views of mesosomal plate. 
fits the narrower headed form represented by two female specimens in the British Museum Collection. The general characters of these are as found in the females belonging to Brüelia tasniemae sp. nov. and Brüelia tasniemae variegatus ssp. nov. and no reliable characters can be found on which to separate them. The characters of the tergal plates, genital plate, and abdominal chaetotaxy although somewhat different in these specimens, cannot be considered reliable as long as a significant number of males and females are not available for examination. This species is provisionaly mentioned here for reference by future workers.

\section{Abdominal Chaetotaxy}

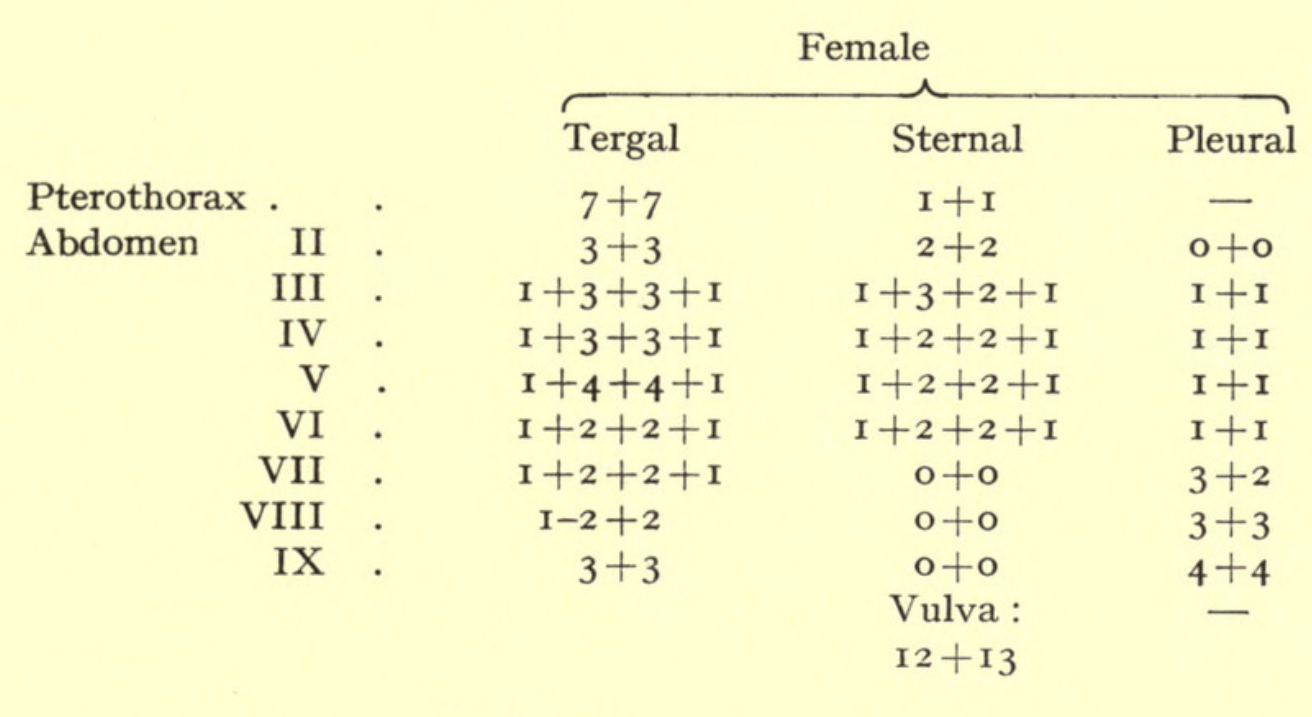

Measurements (mm.)

Female

\begin{tabular}{|c|c|c|c|}
\hline \multicolumn{2}{|c|}{$\begin{aligned} \text { Head : pre-antennal } \\
\text { hind head } .\end{aligned}$} & & $\begin{array}{l}0.285 \times 0.486 \\
0.300 \times 0.566\end{array}$ \\
\hline Prothorax & .. & & $0.097 \times 0.327$ \\
\hline Pterothorax & . & & $0.232 \times 0.522$ \\
\hline Abdomen & . & & $\mathrm{I} \cdot 548 \times 0.76 \mathrm{I}$ \\
\hline $\mathrm{L}: \mathrm{B}$ of pre-a & ntenna & & I : $1 \cdot 705$ \\
\hline $\mathrm{L}: \mathrm{B}$ of hind & head . & & $I: I \cdot 83$ \\
\hline Cephalic inde & $\mathrm{x}$ & 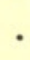 & I : 0.95 \\
\hline
\end{tabular}

Female. Head almost as long as broad. Marginal carina complete above and interrupted ventrally, with a slight concavity and feeble sclerotization in the middle. Ventral carina well formed and fused anteriorly to the ventral component of the marginal carina.

Tergal plates well developed, approximate on segment II-VIII and entire on IX. Tergal plates III-VIII with two colourless spherical areas, tips of each broken.

Material examined. Two females from Corvus albus Müller from Sudan, slide no. 7942 in Meinertzhagen collection (British Museum (Nat. Hist.)). 

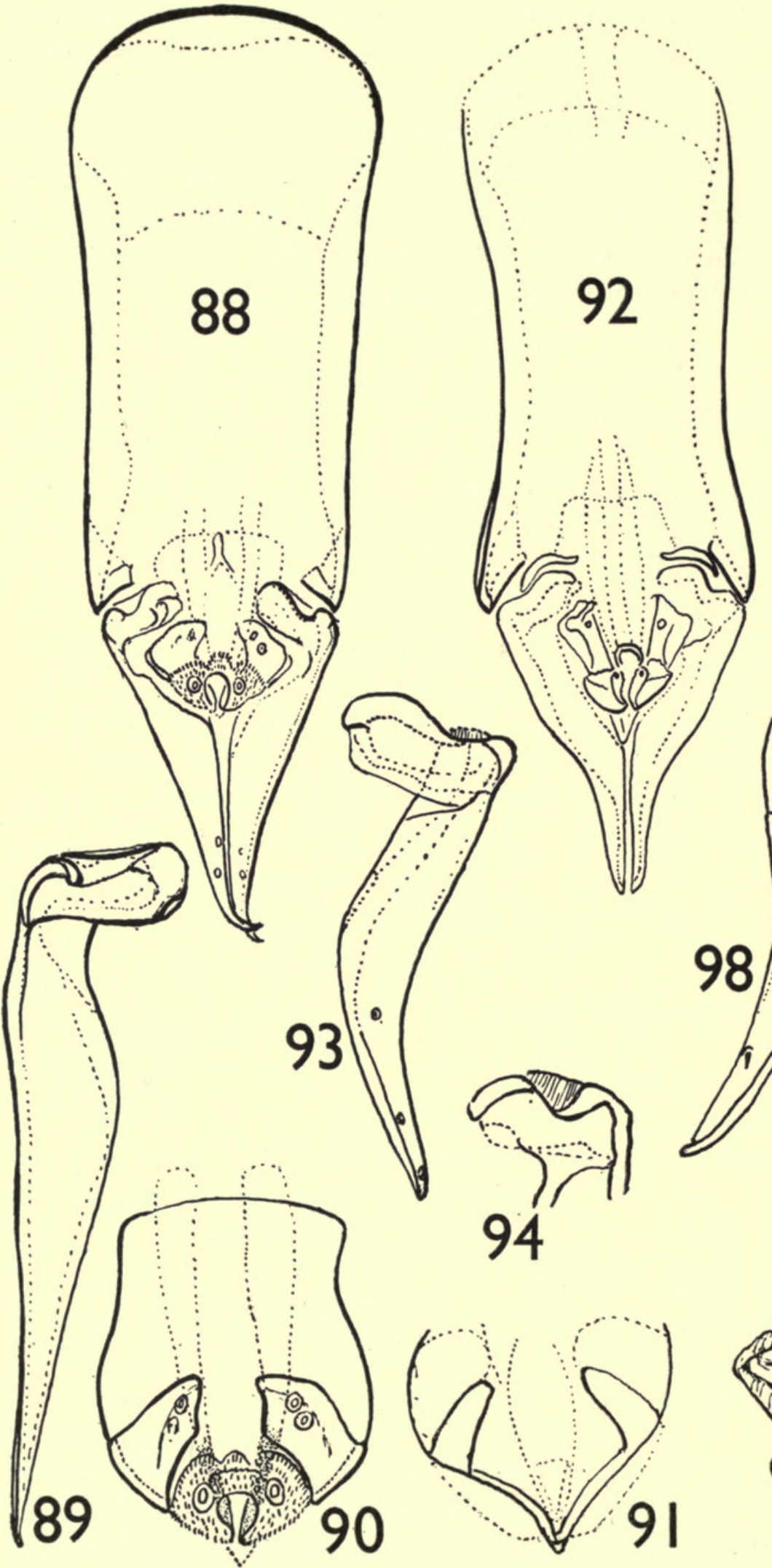
Brüelia latifasciata (Piaget), I880

(Text-figs. 24, 56-57)

Nirmus latifasciata Piaget, I88o, Pédiculines, I43, pl. II, fig. II.

Type host : ? Corvus enca enca (Horsfield).

Clay (I940) has shown that Brüelia latifasciata was described from specimens probably obtained from Corvus e. enca (Horsfield) and that "Xulla mangola" as mentioned by Piaget was only the name of a locality. This single type female in the British Museum (Nat. Hist.) has been examined and is mentioned here for reference. We have not been able to examine other material from the type host and resolve the present confusion.

Female. Head triangular, marginal carina interrupted medianly, and anterior margin at this point hyaline. Dorsal pre-antennal suture distinct. Dorsal anterior plate present. Preocular nodus runs across to meet pre-antennal nodus. Ventral carina well formed, but comparatively less sclerotized than marginal carina. The number and arrangement of setae of the head as in other Brüelia species.

Tergal plates II-VIII and XI interrupted in the middle, while plate IX-X is entire. Sternal plates II-VI distinct and median. Genital plate triangular. Chaetotaxy as given below.

\section{Abdominal Chaetotaxy}

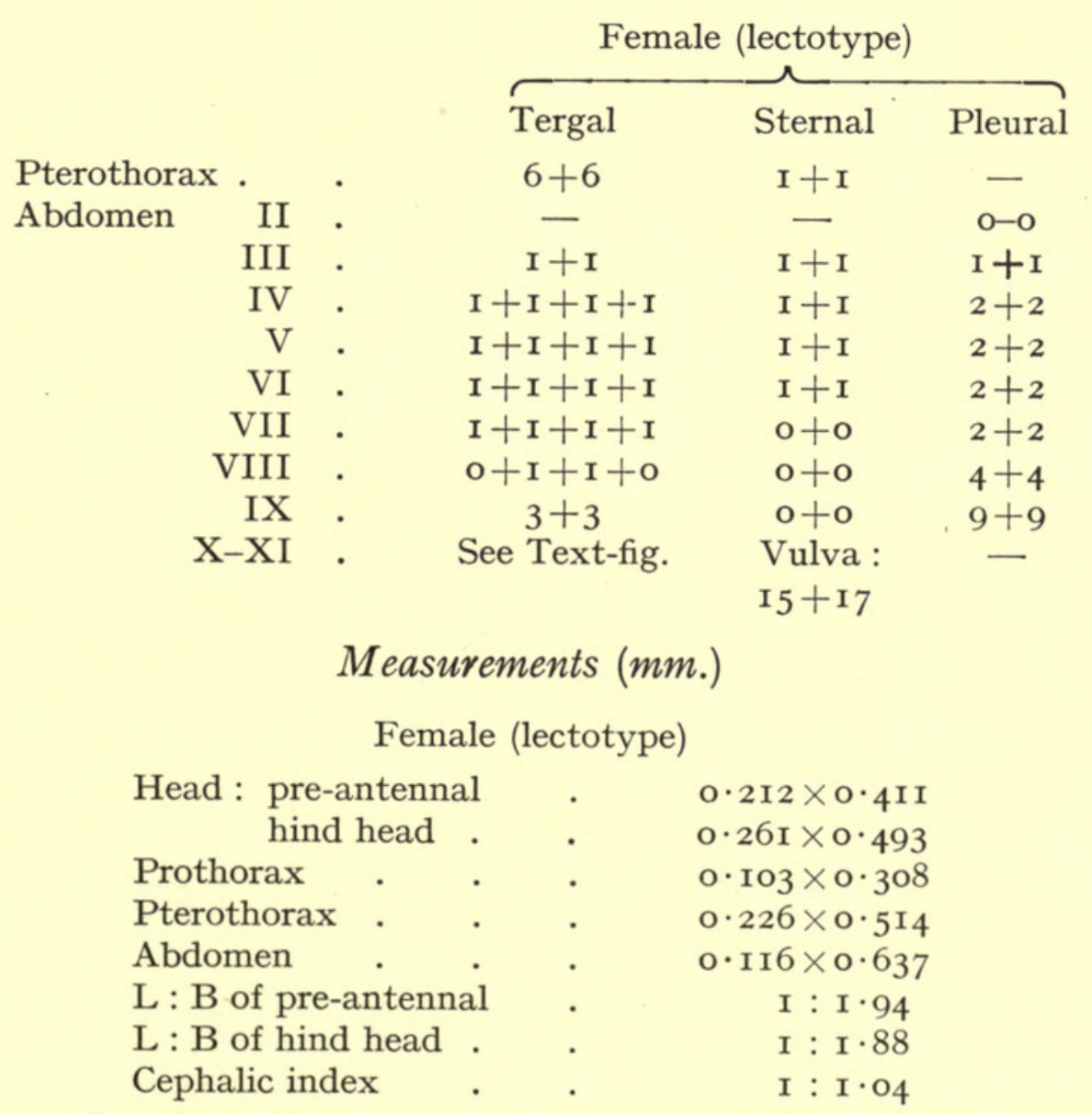

Material examined. One female (Lectotype) in British Museum (Nat. Hist.). 

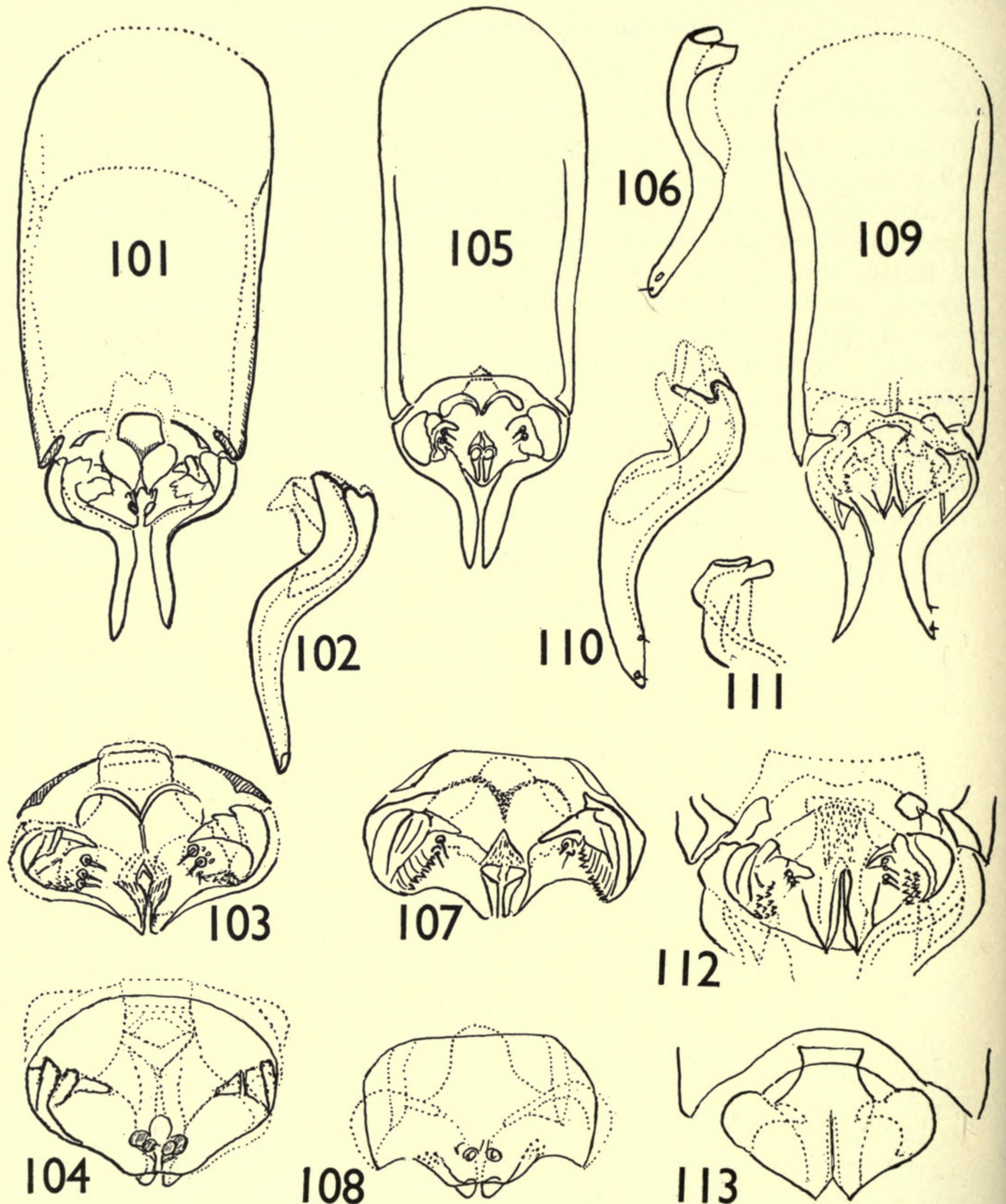

FIgS. IOI-II3. Male genital armatures: (IOI-IO4) Brüelia atherae sp. nov.: (IOI)

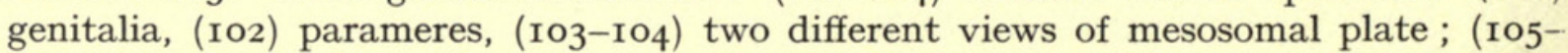
I08) Brüelia cryptoleucus sp. nov.: (I05) genitalia, (I06) paramere, (I07-Io8) two different views of mesosomal plate ; (I09-II3) Brüelia varia (Burmeister) : (I09) genitalia, (IIO) paramere, (III) proximal head of parameres, (II - II $_{3}$ ) two different views of mesosomal plate. 
Brïelia rotundata (Osborn), 1896

(Text-figs. 25, 58-59)

Nirmus rotundata Osborn, I896, Bull. U.S. Bur. Ent. (n.s.), 5 : 226.

Type host : Corvus corone brachyrhynchos Brehm.

This is a broad-headed form distinguished from allied forms by the greater breadth of the temples, tergal plates and chaetotaxy. There are no males of this species in the British Museum (Nat. Hist.) collection and therefore comparison with allied species is difficult ; the following description is provisionally provided to distinguish the females.

Female. Head broader than long. Marginal carina entire, modified medially, with hyaline anterior margin. Dorsal suture present. Ventral carina well formed, fused to the anterior marginal carina. Tergal plates II-VIII approximate, IX entire, X-XI approximate. Sternal plates II-VI well formed. Genital plate conical, with obtuse apical angle.

\section{Abdominal Chaetotaxy}

\begin{tabular}{|c|c|c|c|c|}
\hline & & & $\underbrace{\text { Female }}$ & \\
\hline & & Tergal & Sternal & Pleural \\
\hline Pterothorax & . & $8-9+8-9$ & $\mathbf{I}+\mathbf{I}$ & $0+o$ \\
\hline Abdomen II & . & $\mathbf{I}+\mathbf{I}+\mathbf{I}+\mathbf{I}$ & $I+I$ & $o+o$ \\
\hline III & . & $I+I+I+I$ & $I+I-2$ & $2+I-2$ \\
\hline IV & . & $\mathbf{I}+\mathbf{I}+\mathbf{I}+\mathbf{I}$ & $2+2-3$ & $3+3$ \\
\hline $\mathrm{V}$ & . & $I+I+I+I$ & $2+2-3$ & $3+3$ \\
\hline VI & . & $I+I+I+I$ & $2+2-3$ & $3-4+3-5$ \\
\hline VII & . & $I+I-2+I-2+I$ & $0+0$ & $3-4+4$ \\
\hline VIII & . & $\mathrm{I}-2+\mathrm{I}-2+\mathrm{I}-2+\mathrm{I}-2$ & $0+o$ & $4+4$ \\
\hline IX & . & $\mathrm{I}+5+4-5+\mathrm{I}$ & $0+0$ & $4+4-5$ \\
\hline $\mathrm{X}-\mathrm{XI}$ & . & See Text-fig. & $\begin{array}{c}\text { Vulva : } \\
\text { I5-18+15-20 }\end{array}$ & - \\
\hline
\end{tabular}

Female

\begin{tabular}{|c|c|c|c|}
\hline \multirow{2}{*}{\multicolumn{2}{|c|}{$\begin{array}{l}\text { Head : pre-antennal } \\
\text { hind head }\end{array}$}} & & $\begin{array}{l}0.219 \times 0.507 \\
0.315 \times 0.616\end{array}$ \\
\hline & & & $0.315 \times 0.616$ \\
\hline $\begin{array}{l}\text { Prothorax } \\
\text { Pterothorax }\end{array}$ & - & & $0.089 \times 0.349$ \\
\hline Abdomen & • & & 010 \\
\hline $\mathrm{L}$ : $\mathrm{B}$ of pre- & & & $\mathrm{I} \cdot 335 \times 0 \cdot 80 \mathrm{I}$ \\
\hline L. D or pre- & ntenná & & $I: 2 \cdot I_{5}$ \\
\hline$L: B$ of hind & head & & I : I·95 \\
\hline Cephalic ind & & & I $:$ I $\cdot$ I 5 \\
\hline
\end{tabular}

Material examined. Four females from Corvus corone brachyrhynchos Brehm. from California and Kansas. 


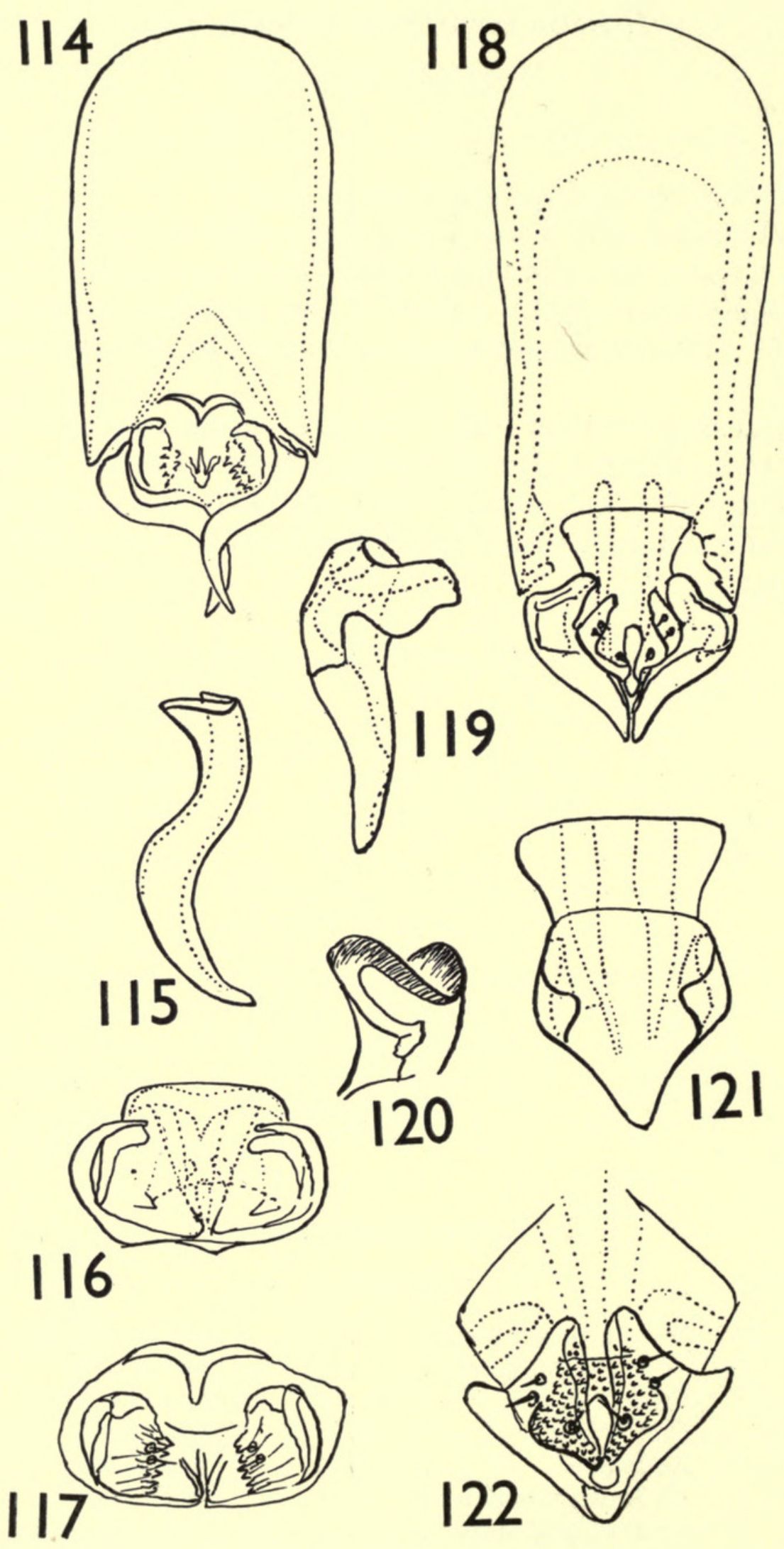

FIgS. II4-I22. Male genital armatures: (II4-II7) Brüelia nawabi sp. nov.: (II4) genitalia, (II5) paramere, (II6-II7) two different views of mesosomal plate ; (II8-I22) Brüelia perwienae sp. nov. : (II8) genitalia, (II9) paramere, (I20) proximal head of paramere, (I2I-I22) different views of mesosomal plate. 
All the known species of Brüelia from Corvus species are discussed and eight new species and three new subspecies are described. The species of previous authors are redescribed and figured.

\section{LIST OF SPECIES AND SUBSPECIES DISCUSSED}

(Type hosts in bold type)

I. Brüelia argula (Burmeister), I838.

Corvus corax corax.

Corvus c. laurencei.

Corvus c. tingitanus.

Corvus c. ruficollis.

2. Brüelia afzali sp. nov.

Corvus cryptoleucus.

3. Brïelia atherae sp. nov.

Corvus corax laurencei.

4. Brüelia bipunctata (Rudow), I87o.

Corvus albus.

5. Brüelia cryptoleucus sp. nov.

Corvus cryptoleucus.

6. Brüelia latifasciata (Piaget), I880.

Corvus enca enca.

7. Brüelia leucocephalus (Nitzsch), I866.

Corvus albicollis.

Corvus affinis.

8. Brüelia nawabi sp. nov.

Corvus capensis.

9. Brüelia perwienae sp. nov.

Corvus nasicus.

I0. Brüelia quadrangularis (Rudow), I869.

Corvus albus.

Corvus corax edithae.

II. Brüelia rotundata (Osborn), I896.

Corvus corone brachyrhynchos.

I2. Brüelia saliemi sp. nov.

Corvus splendens splendens.

Corvus s. zugmeyeri.

13. Brüelia saliemi mollii ssp. nov.

Corvus coronoides macrorhynchus.

Corvus c. intermedius.

Corvus c. colonorum.

I4. Brüelia tasniemae sp. nov.

Corvus frugilegus frugilegus. 
I5. Brüelia variegata sp. nov.

Corvus capensis.

I6. Brüelia theresae sp. nov.

Corvus rhipidurus.

I7. Brüelia uncinosa (Burmeister), I838.

Corvus corone cornix.

Corvus c. sardonius.

I8. Brüelia uncinosa plena ssp. nov.

Corvus c. corone.

I9. Brüelia varia (Burmeister), I838.

Corvus monedula spermologus.

Corvus m. monedula.

Corvus m. soemoeringii.

Corvus frugilegus frugilegus.

Corvus f. tschusii.

Corvus corone corone.

Corvus corone orientalis.

\section{HOST (CORVIDAE) PARASITE (BRÜELIA) INDEX}

Corvidae Host

Aphelocoma coerulescens californica (Vigors)

Corvus albus Müller

Covus albicollis Latham

Corvus capensis Licht.

Corvus corax corax Linn.

Corvus corax edithae Phillips .

Corvus corax laurencei Hume

Corvus corax tingitanus Irby .

Corvus corax ruficollis Lesson

Corvus corone brachyrhynchos Brehm.

Corvus corone corone Linn.

Corvus corone cornix Linn.

Corvus corone orientalis Eversman .

Corvus corone sardonius Kleinschmidt

Corvus coronoides colonorum Swinhoe

Corvus coronoides intermedius Adams

Corvus coronoides macrorhynchus Warler

Corvus cryptoleucus Couch.

Corvus enca enca (Horsfield) .

Corvus frugilegus frugilegus Linn.

Corvus frugilegus tschusii Hartert

\section{Brüelia Species}

deficiens (Piaget), I885.

bipunctata (Rudow), I870.

quadrangularis (Rudow), I869.

leucocephalus (Nitzsch), I866.

nawabi sp. nov.

variegata sp. nov.

argula (Burmeister), 1838 .

quadrangularis (Rudow), 1869.

avgula (Burmeister), I838.

atherae sp. nov.

argula (Burmeister), I 838 .

argula (Burmeister), 1838 .

atherae sp. nov.

rotundata (Osborn), I896.

uncinosa plena ssp. nov.

varia (Burmeister), 1838 .

uncinosa (Burmeister), 1838 .

varia (Burmeister), 1838 .

uncinosa (Burmeister), 1838 .

saliemi mollii ssp. nov.

saliemi mollii ssp. nov.

saliemi mollii ssp. nov.

afzali $\mathrm{sp}$. nov.

cryptoleucus sp. nov.

latifasciata (Piaget), I88o.

tasniemae sp. nov.

varia (Burmeister), $\mathbf{1} 88_{3}$.

varia (Burmeister), 1838 . 
Corvidae Host

Corvus monedula monedula Linn. Corvus monedula soemoeringii Fisher Corvus monedula spermologus Vieillot Corvus nasicus Temminck Corvus rhipidurus Hartert Corvus splendens splendens Vieillot Corvus splendens zugmeyeri Laubmann Cyanocitta cristata cristata (Linn.) . Cyanocitta stellari frontalis (Ridgway) Cyanocorax cyanomelas (Vieillot) Cyanopica cyanus cooki Bonaparte Dendrocitta rufa vagabunda (Latham) Garrulus glandarius glandarius (Linn.) Garrulus glandarius krynicki Kaleniczenko Garrulus glandarius rufitergum Hartert . Garrulus glandarius theresae Meinertzhagen Nucifraga caryocatactes caryocatactes (Linn.) Nucifraga caryocatactes multipunctata Gould Perisoreus infaustus infaustus Linn.

Ptilostomus afer (Linn.)

Pica pica bactriana Bonaparte pica pica hudsonia (Sabine) Pica pica leucoptera Gould Pica pica nuttalli Audebon Pica pica sericea Gould Podoces biddulphi Hume Podoces hendersoni Hume Pyrrhocorax pyrrhocorax docilis (Gmelin) Pyrrhocorax graculus graculus (Linn.) Pyrrhocorax pyrrhocorax himalayanus Gould Pyrrhocorax pyrrhocorax pontifex Stresemann Pyrrhocorax pyrrhocorax pyrrhocorax (Linn.) Urocissa flavirostris cuculata Gould Urocissa melanocephala occipitalis (Blyth) Xanthura yncas galeata Ridgway Zavattariornis stressemanni Moloni. Probably a member of the Corvidae

\section{Brüelia Species}

varia (Burmeister), $\mathrm{I} 838$. varia (Burmeister), $\mathrm{I} 838$. varia (Burmeister), $\mathrm{I} 838$. perwienae sp. nov. theresae sp. nov. saliemi sp. nov. saliemi sp. nov. clayae Ansari, I956. deficiens (Piaget), I885. nitzschi Kéler, I938. deficiens (Piaget), I885. meinertzhageni Ansari, I956. glandarii (Denny), I842. glandarii (Denny), I842. glandarii (Denny), I842. glandarii (Denny), I842. olivacea (Burmeister), I838. multipunctata (Clay), I936. perisorius Ansari, 1956. zohrae Ansari, 1956. biocellata (Piaget), I88o. biocellata (Piaget), I88o. biocellata (Piaget), I88o. biocellata (Piaget), I88o. biocellata (Piaget), I880. koslovae (Clay), I936. koslovae (Clay), I936. biguttata docilis Ansari, I956. biguttata (Kellogg \& Paine), I9I4. biguttata (Kellogg \& Paine), I9I4. biguttatus (Kellogg \& Paine), I9I4. biguttata (Kellogg \& Paine), I9I4. husaini, Ansari, I956. hussaini Ansari, 1956. hopkinsi Ansari, I956. zavattariornis Ansari, I956. hamatofasciata (Piaget), 1890.

\section{REFERENCES}

BEDFORD G. A. H. I932. A synoptic check-list and host-list of ectoparasites found on South African Mammalia, Aves and Reptilia. Repts. Vet. S. Afr. 223-523.

Burmeister, H. I838. Pelzfresser. Handbuch der Entomologia 2 : 418-443.

CARriker, M. A. I902. Description of new Mallophaga from Nebraska. Jour. N.Y. Ent. Soc. $10(4): 216-229$.

Clay, T. I95I. An introduction to a classification of the Avian Ichnocera (Mallophaga), Part I. Trans. R. ent. Soc. London 102 (2) : I7I-I94.

1936. New species of Mallophaga recorded from Asiatic birds. Proc. zool. Soc. Lond. 1935 : 908. Fig. 3, pl. I.

Denny, H. I842. Monographia Anoplurorum Britanniae. London.

Giebel, C. G. I874. Insecta Epizoa. Leipzig.

HARrison, H. I9I6. The genera and species of Mallophaga. Parasitology, Cambridge 9: I-I56. 
Hopkins, G. H. E. \& Clay, T. I952. A Check List of the Genera and Species of Mallophaga. London.

KellogG, V. K. \& Paine, J. H. I9I4. Mallophaga from birds (mostly Corvidae and Phasianidae) of India and neighbouring countries. Rec. Ind. Mus. Calcutta 10 (4) : 2I 7-243.

I908. Wytsman Genera Insectorum 66 : Mallophaga.

K filer, S. I938. Ueber einige Mallophagen aus Paraquay und Kamerum. Arbeit. morph. taxon. ent. Berlin-Dahlem, 232, fig. 2.

Nitszch, C. L. I8I8. Die Familien und Gattungen der Thierinseckten (Insecta epizoica) als ein Prodromus der Naturgeschichte derselben. Germar's Mag. Ent. 3 : 26I-316.

1866. Die im zoologischen Museum der Universitat Halle aufgestellten Epizoan nebst Beobachtungen uber dieselben. Z. ges. Naturw. 37 : 173-179.

Osborn, H. I896. Insects affecting domestic animals. Bull. U.S. Bur. Ent. (n.s.) 5 : 302 pp.

Piaget, E. I880. Les Pediculines. Leyden.

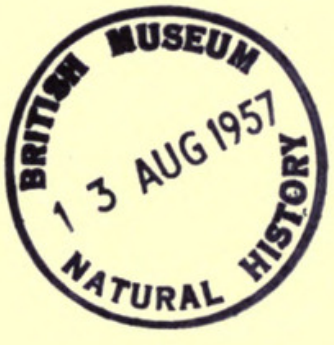




\section{$2 \mathrm{BHL}$ Biodiversity Heritage Library}

Ansari, M. Atiqur Rahman. 1957. "A revision of the Brüelia (Mallophaga) species infesting the Corvidae. Part II." Bulletin of the British Museum (Natural History) Entomology 5, 143-182. https://doi.org/10.5962/bhl.part.1509.

View This Item Online: https://www.biodiversitylibrary.org/item/19644

DOI: https://doi.org/10.5962/bhl.part.1509

Permalink: https://www.biodiversitylibrary.org/partpdf/1509

\section{Holding Institution}

Natural History Museum Library, London

\section{Sponsored by}

Natural History Museum Library, London

\section{Copyright \& Reuse}

Copyright Status: In copyright. Digitized with the permission of the rights holder.

Rights Holder: The Trustees of the Natural History Museum, London

License: http://creativecommons.org/licenses/by-nc-sa/4.0/

Rights: http://biodiversitylibrary.org/permissions

This document was created from content at the Biodiversity Heritage Library, the world's largest open access digital library for biodiversity literature and archives. Visit BHL at https://www.biodiversitylibrary.org. 